Exploring Service-Learning Outcomes and Experiences for Low-Income, FirstGeneration College Students: A MixedMethods Approach

\author{
Travis, T. York
}

This article was originally published at:

https://journals.sfu.ca/iarslce/index.php/journal/article/view/201/176

Recommended Citation

York, T. T. (2016). Exploring service-learning outcomes and experiences for low-income, firstgeneration college students: A mixed-methods approach. International Journal of Research on Service-Learning and Community Engagement, 4(1), 309-342. 


\title{
Exploring Service-Learning Outcomes and Experiences for Low-Income, First-Generation College Students: A Mixed-Methods Approach
}

\author{
Travis T. York \\ Association of Public \& Land-grant Universities, Washington, DC
}

\begin{abstract}
This study explored the service-learning experiences of low-income, first-generation college students using a mixed-methods design that drew upon a national longitudinal dataset and in-depth, face-to-face interviews conducted over the course of a year and a half at three institutions in three states. The purpose of this study was to increase understanding of the outcomes related to service-learning participation for low-income, first-generation college students. Findings indicated that participation in service-learning courses was significantly positively related to the development of several academic and affective outcomes related to increased academic success. The presence of divergent findings from the two data streams also indicated particular complexity in measuring development for low-income and first-generation students-a complexity not found in the overall student population. The author discusses specific implications of this study for practitioners, college and university administrators, researchers, and policy makers.
\end{abstract}

Keywords: higher education, service-learning, low-income, first-generation

Research on service-learning has grown substantially in the past three decades and has been invaluable to the exploration of student learning and development; however, the bulk of this research has focused on White students from middle- and upper-class backgrounds. While low-income, firstgeneration (LIFG) students have been historically less likely to participate in service-learning (Astin \& Sax, 1998), recent research has indicated that service-learning participation rates are equal between LIFG college students and their peers (York, 2015). This increase in participation is likely due to a substantial, nationwide increase in opportunities for students to engage in service-learning courses (Campus Compact, 2010, 2011, 2012). Despite these increases, little empirical research on the experiences or gains associated with LIFG students' participation in service-learning has been conducted. Extant servicelearning research has suggested that students who participate in service-learning experience significant gains in academic and affective outcomes (Astin, Vogelgesang, Ikeda, \& Yee, 2000; Eyler \& Giles, 1999; Vogelgeslang \& Astin, 2000); however, external generalization of these findings has not been supported by the research. Furthermore, such generalizations are called into question by the nature of the cognitive processes involved in service-learning. In their seminal book, Where is the Learning in Service-Learning, Eyler and Giles (1999) explored the impact of encountering the "other" through service-learning experiences. They concluded that service-learning participation is related to reductions in stereotypes as well as increases in developing tolerance and appreciation of other cultures. These findings are compatible with much of Dewey's $(1925,1938)$ theory of experiential learning, but do such experiences with the 'other' occur - or occur in similar ways - for LIFG students?

An examination of the experiences and outcomes associated with service-learning pedagogy are needed to evaluate its effectiveness in contributing to LIFG students' success. Such an exploration is particularly important given the asset approach of service-learning, which capitalizes on students' backgrounds as rich components of the learning environment, versus a deficit approach, which treats students' backgrounds as limitations or barriers to success (Rendón, 1994). This article addresses this gap 
in service-learning research via a mixed-methods study. The purpose of the study and corresponding research questions are outlined in the next section followed by a review of the literature, including a discussion of the theoretical and conceptual frameworks undergirding the study. The article then outlines the study's methodology_parsed into two phases — and describes the points of interface between the quantitative and qualitative strands of data. A detailed discussion of the findings, organized by the research questions, follows. Finally, the article discusses conclusions and implications for practice, policy, and future research.

\section{Purpose of the Study}

The purpose of this study was to increase the understanding of service-learning outcomes for low-income, first-generation college students. The study utilized the Serve America Act's definition of service-learning as a regular for-credit course in which students engage in service to meet the needs of a community and to achieve the intended learning goals of the course (Corporation for National and Community Service [CNCS], 2008). As pedagogy, service-learning uses structured reflection and is inherently aimed at increasing students' civic responsibility. CNCS's definition establishes several clear criteria for service-learning, most importantly that it is an educational method-a criterion that clearly separates service-learning from community service or volunteerism.

The study explored the following research questions:

- Research Question 1: What latent constructs are present for the sample of LIFG college students?

- Research Question 2: How does participation in service-learning relate to college GPA, the Civic Awareness, and any latent constructs for LIFG students?

\section{Literature Review}

\section{Academic Outcomes}

In a review of service-learning research conducted between 1993 and 2000, Eyler, Giles, Stenson, and Gray (2001) found 24 published articles that included findings supporting the conclusion that servicelearning has a positive impact on students' learning. This scholarly attention could be attributed to the centrality of the reported outcomes to the raison d'être of higher education. In 2000, Astin, Vogelgesang, Ikeda, and Yee released a landmark report titled How Service Learning Affects Students. The report discussed findings from a nationally representative longitudinal study of 22,236 undergraduates at baccalaureate-granting institutions. A major finding indicated that service-learning curricula resulted in increased student gains over and above the gains associated with community service alone. The authors also found that service-learning participation was related to significantly higher growth in GPA and critical thinking. These findings about service-learning's impact on academic outcomes confirmed the results of many other researchers (Astin \& Sax, 1998; Eyler \& Giles, 1999; Miller, 1994; Strage, 2000; Ward, 2000).

In 2011, Celio, Durlak, and Dymnicki conducted a meta-analysis of the impact of service-learning participation on college students, finding that participation was positively related to academic achievement (mean $d=.31, p \leq .05$ ). Similarly, Yorio and Ye (2012) conducted a meta-analysis of outcomes related to service-learning experiences and found that participation had a positive effect on cognitive learning in aggregate (est. $\delta=.52, p \leq .05$ ). Yorio and Ye used a broad operationalization of cognitive learning that included both objective academic outcomes (e.g., GPA, course completion, etc.) as well as subjective affective outcomes such as self-perception of growth in higher order cognitive skills 
(i.e., problem solving and critical thinking skills). Though both meta-analyses supported the inclusion of academic outcomes in this study, neither parsed the samples to explore differential effects upon various subpopulations of students.

\section{Affective Outcomes}

In a meta-analysis of service-learning research, Eyler et al. (2001) found 17 articles indicating that service-learning had a positive impact on developing interpersonal skills, and another 31 found positive effects related to reducing stereotypes. For example, one mixed-methods study found that service-learning participation was related to the reduction of stereotypes, an increase in sense of community and feelings of similarity with the 'other', and an increase in tolerance of and appreciation for other cultures (Eyler \& Giles, 1999). Eyler and Giles (1999) argued that service-learning provided students with an opportunity to interact with people whose experiences and perspectives are different from their own. Additionally, 21 studies published between 1993 and 2000 found that service-learning participation was positively related to students' sense of social responsibility and citizenship skills (Eyler et al., 2001). These studies found that students who participated in service-learning exhibited increased outcomes in several areas of civic engagement, including future civic participation (Andolina, Jenkins, Zukin, \& Keeter, 2003; Astin et al., 2000; Astin \& Sax, 1998; Kahne \& Sporte, 2008).

Research on service-learning has produced significant evidence supporting the efficacy of servicelearning as a pedagogy that enhances the growth and development for the majority of students. What has yet to be demonstrated, however, is the utility of service-learning to mitigating common barriers to LIFG students' success. According to a 2008 Pell report, approximately $24 \%$ of undergraduate college students in the U.S. (4.5 million individuals) are both low-income and first-generation, and these students have an average persistence rate of $11 \%$ - startling when compared with the overall national student population average of 55\% (Engle \& Tinto, 2008). A substantial body of research has indicated that LIFG students, on average, experience a variety of complex barriers to success-including limited financial, social, and/or cultural capital (Forsyth, \& Furlong, 2003; Horn, 1997; Pascarella \& Terenzini, 2005; Perna, 2002; Walpole, 2003). In light of past findings regarding the outcomes associated with participation in servicelearning, it is unsurprising that institutional attention given to LIFG student success has resulted in several well-intended but insufficiently evaluated pedagogies, including service-learning.

\section{Theoretical and Conceptual Frameworks}

The assumption that service-learning experiences for low-income, first-generation students are similar to those of majority students becomes questionable when examined via Dewey's (1938) theories of learning, which served as the theoretical framework for this study. Indeed, several service-learning scholars have positioned Dewey's learning theories, especially the principles of continuity and interaction, as the theoretical foundations of service-learning (Benson, Harkavy, \& Puckett, 2007; Giles \& Eyler, 1994; Jacoby \& Associates, 1996; Saltmarsh, Hartley, \& Clayton, 2009). Dewey argued that learning is the application of knowledge derived from the transaction between an individual-including their background - and the environment within a particular situation. Dewey's principles of continuity and interaction highlight the role individuals' experiences (past, present, and future) have in learning and in the educational process, suggesting that LIFG students' backgrounds uniquely shape their experiences in service-learning courses and the subsequent outcomes. This study also utilized Astin's (1991) inputenvironment-outcome model as a conceptual framework for its design. Together, these theories and conceptual framework allowed the researcher to account for the effect of students' background characteristics (inputs) and the experience of participating in service-learning courses while in higher education (environment) upon specific outcomes. This integration of frameworks (Figure 1) served as the theoretical and conceptual foundation guiding this study's exploration of LIFG students' service-learning experiences and outcomes (York, 2015). 


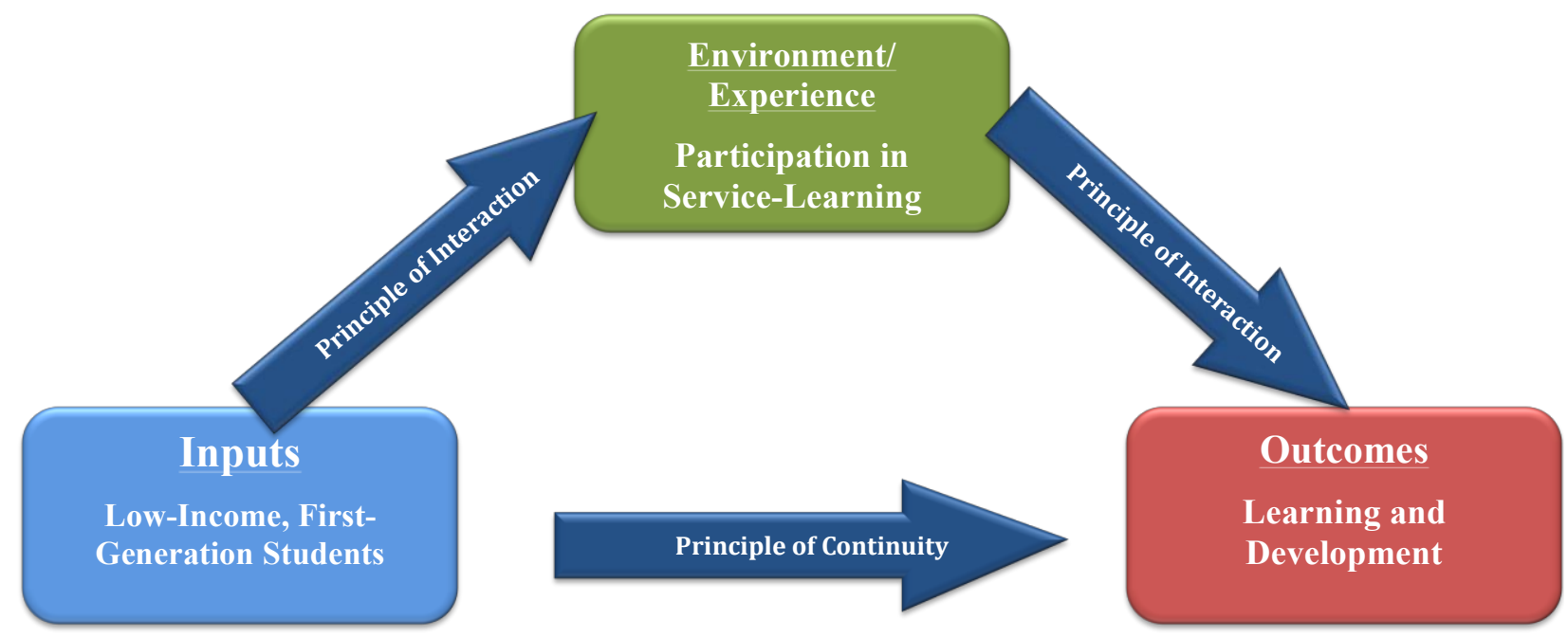

Figure 1. York's theoretical and conceptual model of service-learning.

\section{Methods}

This study examined the variation in outcomes for LIFG students who participated in service-learning courses, disaggregated by student characteristics, and explored their experiences with service-learning via an explanatory sequential mixed-methods design (Creswell, 2003; Creswell \& Plano Clark, 2011). This design included two phases. The first quantitative phase used nationally representative, longitudinal, data from UCLA's Higher Education Research Institute (HERI). The sample included over 5,000 participants from 87 private and public universities across the country. The second qualitative phase used the results from the quantitative analysis to inform the construction of a semi-structured interview protocol for indepth, face-to-face interviews with LIFG college students who had participated in at least one servicelearning course while in college. Interviews were aimed at exploring the service-learning experience and resulting outcomes for LIFG students.

In accordance with reports from the National Center for Education Statistics (NCES), low-income status was operationalized as students from families with annual incomes at or below $\$ 30,000$ (Choy, 2000, 2001, 2003). First-generation status was operationalized as students whose parents' or legal guardians' educational attainment was less than "some college" (qualifying responses included one of the following: "grammar school or less," "some high school," or "high school graduate"). Though this strict operationalization narrowed the study's sample, it helped to more accurately capture the intended student group and thereby increase the study's validity and trustworthiness. This design also allowed for the exploration of divergent findings resulting from the two data phases. Tashakori and Teddlie (2010) argued that mixed-methods research has the ability to produce both convergent and divergent findings and to allow for deeper insight into complex phenomena.

\section{Analytical Procedure}

\section{Quantitative analytical procedure}

Data were cleaned and multiple imputation analysis was utilized to accommodate missing data (i.e., nonmonotone and missing completely at random [MCAR]). An analysis of variance (ANOVA) and corresponding chi-square tests were conducted to compare the sample of LIFG college students who participated in service-learning courses (LIFG Participants) with the sample of LIFG college students who did not participate in service-learning courses (Nonparticipants). Similar analyses were used to 
compare LIFG Participants to the overall college students who participated in service-learning courses.

While cumulative college GPA and Cooperative Institutional Research Program (CIRP) civic awareness factors were included in this study based on past service-learning research (e.g., Astin et al., 2000; Astin \& Sax, 1998; Sax, Astin, \& Astin, 1996), the lack of empirical work focused on the outcomes of service-learning participation for LIFG students warranted an exploration of potential latent constructs. As such, an exploratory factor analysis (EFA) was also used to explore the possibility of any latent outcome constructs specific to this population's experience with service-learning. In addition, ordinary least squares (OLS) regression modeling was used for each dependent variable. Independent variables were blocked into the following categories based upon the integrated conceptual and theoretical framework: student pre-college characteristics, student pre-college experiences, student college characteristics, and institutional characteristics. The dichotomous service-learning variables entered the models last to investigate the amount of variance explained by this experience. For each OLS regression, the errors were normally distributed, validating the use of this analytical method.

\section{Qualitative analytic procedure}

Individual, face-to-face interviews were conducted with each of the participants. A semi-structured interview protocol was developed to allow for a measure of consistency in primary interview questions while also allowing for deep exploration of specific phenomena through follow-up questions (Bogdan \& Biklen, 2007; Maxwell, 2005). Interviews were audio recorded, transcribed, and read for major themes. A two-tiered coding structure (open and categorical) was used to analyze the data. After initial coding was completed, broad thematic coding was performed to organize transcript passages into themes (Merriam, 2002). Themes were then analyzed in an effort to generate preliminary findings. Member checks were conducted with the preliminary findings to increase validity of the results. Reflexive researcher memos were also employed throughout the data collection and analysis processes to reveal emergent themes and allow for researcher bracketing (Maxwell, 2005). Finally, peer audits of the findings were conducted with two faculty colleagues.

\section{Samples}

\section{Quantitative sample}

Of the 5,270 participants in the dataset, 312 participants from 69 institutions met the study criteria of being both low-income and first-generation. Table 1 provides detailed information regarding the institutional type and LIFG participants' gender, race, and service-learning participation. 
Table 1. Sample Demographics for LIFG Students

\begin{tabular}{|c|c|c|c|}
\hline & Institutions \% (n) & Students \% (n) & \\
\hline \multicolumn{4}{|l|}{ Institutional Type } \\
\hline Public & $53.6(37)$ & $70.5(220)$ & \\
\hline Private & $46.4(32)$ & $\underline{29.5(92)}$ & \\
\hline Total: & $100(69)$ & $100(312)$ & \\
\hline \multicolumn{4}{|l|}{ Service- Learning Participation } \\
\hline Gender & No \% (n) & Yes \% (n) & Total \% (n) \\
\hline Male & $38.6(71)$ & $26.6(34)$ & $33.7(105)$ \\
\hline Female & $61.4(113)$ & $73.4(94)$ & $66.3(207)$ \\
\hline Total: & $100(184)$ & $100(128)$ & $100(312)$ \\
\hline Race/Ethnicity & No \% (n) & Yes \% (n) & Total \% (n) \\
\hline Asian & $23.4(43)$ & $7.0(9)$ & $16.7(52)$ \\
\hline Black & $12.5(23)$ & $18.8(24)$ & $15.1(47)$ \\
\hline Hispanic & $39.1(72)$ & $42.2(54)$ & $40.4(126)$ \\
\hline White & $13.0(24)$ & $14.8(19)$ & $13.8(43)$ \\
\hline Other Race/Ethnicity & $3.8(7)$ & $5.5(7)$ & $4.5(14)$ \\
\hline Multicultural & $8.2(15)$ & $11.7(15)$ & $9.6(30)$ \\
\hline Total: & $100(184)$ & $100(128)$ & $100(312)$ \\
\hline
\end{tabular}

The overall student sample included 5,270 cases, of which $43.3 \%(\mathrm{n}=2,281)$ had participated in at least one service-learning course (overall participants). Table 2 provides detailed information regarding the institutional type and gender, race, and service-learning participation for the overall sample. 
Table 2. Sample Demographics for Overall Students

\begin{tabular}{|c|c|c|c|}
\hline & Institutions \% (n) & Students \% (n) & \\
\hline \multicolumn{4}{|l|}{ Institutional Type } \\
\hline Public & $50.6(44)$ & $57.8(3,046)$ & \\
\hline Private & $49.4(43)$ & $\underline{42.2(2,224)}$ & \\
\hline Total: & $100(87)$ & $100(5,270)$ & \\
\hline \multicolumn{4}{|c|}{ Service- Learning Participation } \\
\hline Gender & No \% (n) & Yes \% (n) & Total \% (n) \\
\hline Male & $39.2(1,171)$ & $29.2(666)$ & $34.9(1,838)$ \\
\hline Female & $\underline{60.8(1,818)}$ & $\underline{70.8(1,615)}$ & $\underline{65.1(3,432)}$ \\
\hline Total: & $100(2,989)$ & $100(2,281)$ & $100(5,270)$ \\
\hline Race/Ethnicity & No \% (n) & Yes \% (n) & Total \% (n) \\
\hline Asian & $11.0(329)$ & $8.0(182)$ & $9.7(511)$ \\
\hline Black & $9.7(290)$ & $11.3(257)$ & $10.4(548)$ \\
\hline Hispanic & $14.6(437)$ & $14.3(327)$ & $14.5(763)$ \\
\hline White & $46.7(1,396)$ & $49.2(1,123)$ & $47.8(2,519)$ \\
\hline Other Race/Ethnicity & $2.8(84)$ & $3.2(73)$ & $3.0(157)$ \\
\hline Multicultural & $15.2(453)$ & $14.0(319)$ & $14.6(772)$ \\
\hline Total: & $100(2,989)$ & $100(2,281)$ & $100(5,270)$ \\
\hline
\end{tabular}

Results of the ANOVA of the independent variables (see Appendix A, Table A1) were used to identify variables with statistical differences between LIFG Participants and Nonparticipants. These results indicated that five variables had significant $(p \leq 0.05)$ differences between participants and nonparticipants: Asian race/ethnicity (7.2\% of participants self-identified as Asian compared to $23.3 \%$ of nonparticipants), math and sciences majors (16.4\% of participants were math and science majors compared to the $26.1 \%$ of nonparticipants), humanities majors (17.2\% of participants were humanities majors compared to $29.3 \%$ of nonparticipants), social science majors (41.4\% of participants were social science majors compared to $20.7 \%$ of nonparticipants), and high school community service participation 1 (91.4\% of participants had participated in community service during high school compared to $77.7 \%$ of nonparticipants). Although the limited potential for selection bias indicated by these differences were fairly well mitigated by their use within the regression analysis as controls, they should still be noted in relation to later findings. For example, the differences in high school service-learning participation (and marginal significance of high school community service participation) reinforced finding from previous literature (Astin et al., 2000; Astin \& Sax, 1998) suggesting that pre-college participation predisposes students to participate in service-learning courses during college.

\section{Qualitative sample}

A total of eight rounds of recruitment were conducted over the course of one year between four institutional sites. Twenty-two students indicated interest in participating; however, only seven of these

1 High school service-learning participation and high school community service participation were captured by the survey instrument as separate questions. 
students met the study's criteria (see Table 3).

Table 3. Interview Participant Demographics

\begin{tabular}{lrrrrrr}
\hline Pseudonym & Gender & Age & Race & Year & $\begin{array}{r}\text { \# of S-L } \\
\text { Courses }\end{array}$ & Major \\
\hline Adam & Male & 31 & White & Senior & 3 & $\begin{array}{r}\text { City and Regional } \\
\text { Planning }\end{array}$ \\
Brooke & Female & 21 & Latina & Junior & 2 & Communications \\
Bob & Male & 30 & Multiracial & Junior & 1 & English \\
Elnora & Female & 18 & Asian & Freshman & 1 & Biological Sciences \\
Joe & Male & 18 & Black & Sophomore & 1 & Psychology \\
Jose & Male & 19 & Latino & Freshman & 2 & Undeclared \\
Roj & Male & 21 & Latino & Junior & 1 & $\begin{array}{r}\text { Finance and Risk } \\
\text { Management }\end{array}$ \\
\hline
\end{tabular}

Two of the seven students volunteered to participate in follow-up interviews, resulting in a total of nine interviews. Participants included three males and one female, and ranged from 18 to 31 years of age. Participants were racially and ethnically diverse (i.e., Asian, Black, Latino/a, Multiracial, and White) and studied a variety of majors. Participants also varied across each academic year, freshman through senior.

\section{Dependent Variables}

Past research heavily influenced the choice of the outcome variables analyzed in this study. The extant literature revealed two general categories of outcomes related to participation in service-learning: academic and affective. Therefore, this study included outcome variables that were both academic and affective in nature. Furthermore, the literature discussing common barriers to LIFG student success indicated that limited cultural and financial resources were related to disproportionately low gains in academic achievement, civic engagement and awareness, and the development of latent constructs present for the LIFG population. In an effort to explore the relationship of service-learning participation within these three outcome constructs, this study ultimately utilized three outcome variables: cumulative college GPA, civic awareness score, and cognitive diversity score.

The CIRP civic awareness score, as prepared by the Higher Education Research Institute (HERI), was used as an outcome variable in this study.2 CIRP's civic awareness scale comprises three individual items: growth in understanding of social problems facing our nation (weight $=7.88$ ), growth in understanding global issues (weight $=3.32$ ), and growth in understanding of the problems facing your community (weight $=2.09$ ). These items describe an understanding or awareness of local and global issues but do not capture the participant's behavior in response to this understanding. As such, this variable distinctively captures students' civic awareness and not civic engagement. Exploratory factor analysis was used to investigate the presence of latent constructs. One 4-item factor $(\alpha=0.814)$ emerged and was named "cognitive diversity." Details regarding the construction of this factor are outlined in the findings section of this article

2 HERI utilizes Item Response Theory in their scale construction. Evidence from their technical report indicates this scale has high internal reliability and validity. 


\section{Independent Variables}

Independent variables likely to contribute to student outcomes based upon the layered conceptual and theoretical model were requested from HERI (Table 4; see Appendix B, Table B1 for item details). Demographic characteristics, first-year views, and pre-college experiences were considered as conceptual inputs, whereas institutional characteristics were considered environmental or experiential variables in the layered model. These variables were chosen to allow for parsing of the data and to more readily isolate the effect of service-learning participation. Previous research has related several high school experiences to cultivating a predisposition for service (Astin et al., 2000; Astin \& Sax, 1998; Sax, Astin, \& Astin, 1996); therefore, three variables were used as controls to better isolate the effect of college servicelearning participation. Dummy codes were created for racial and ethnic groups-Asian, Black, Hispanic, White (reference group), multicultural, and other race/ethnicity; gender-male and female (reference group); and primary undergraduate major - math and science majors, social science majors, preprofessional majors, humanities majors (reference group), and other majors.

Table 4. Independent Variables Grouped Thematically

\section{Demographics}

Race/Ethnicity $^{\dagger} \quad \operatorname{Sex}^{\dagger}$

Low-Income, First-Generation ${ }^{\mathrm{d}}$

\section{First-Year Views (TFS)}

Racial discrimination is no longer a major problem in America $^{\mathrm{d}}$

Realistically, an individual can do little to bring about changes in our society ${ }^{d}$

Affirmative action in college admission should be abolished $^{\mathrm{d}}$
Colleges should prohibit racist/sexist speech on campus ${ }^{d}$

Same-sex couples should have the right to legal marital status $^{\text {d }}$

\begin{tabular}{lc}
\hline & Pre-College Experiences \\
\hline $\begin{array}{l}\text { High School GPA } \\
\text { High School Service-Learning } \\
\text { Participation }^{\mathrm{d}}\end{array}$ & High School Community Service Participation ${ }^{\mathrm{d}}$ \\
\hline & Community Service Required in High School $^{\mathrm{d}}$ \\
\hline Primary Undergraduate Major $^{\dagger}$ & College Experience \\
Participation in Service-Learning Courses $^{\mathrm{d}}$ & Full-Time Enrollment $^{\mathrm{d}}$ \\
\hline
\end{tabular}

\section{Institutional Characteristics}

Public Institution ${ }^{d}$ Institutional Selectivity

Note. ${ }^{\mathrm{d}}$ dichotomous variable. ${ }^{\dagger}$ dummy coded.

\section{Limitations}

Though this study was designed to mitigate limitations of past research, there were several limitations that should be noted. First, the CIRP surveys seek to explore the impact of college by connecting student outcomes with a comprehensive set of college experiences. While the surveys' comprehensive nature allows for the exploration of a variety of experiences and outcomes, they are limited in their specificity in 
some respects. For example, the single survey item that asks about service-learning participation does not capture information on the quality of the experience or the specific number of service-learning courses taken. Additionally, many of the variables investigated in the surveys result from items asking about students' perception of growth or change in various learning and developmental outcomes. Whitt, Nora, Edison, Terenzini, and Pascarella (1999) argued that though students' self-reported information is usually fairly accurate, researchers should nevertheless remain aware that questions asking students to estimate their growth in areas are susceptible to "response set"-a phenomenon whereby participants who answer positively in one portion of a survey are likely to answer positively in later parts. This is one likely cause of the high rate of non-significance within the findings of this study. Additionally, this dataset did not allow for the operationalization of the "low-income" criteria with family size. Instead, a steady threshold (i.e., annual family income equal to or less than \$30,000) was used; however, this figure does account for number of parents or children dependent upon that income. Similarly, this criterion does not account for geographic differences in cost of living.

Finally, the narrow focus of the study's sample resulted in limited cell size of student cases nested within institutional sites. This small cell size limited the analytical method to that of single-level regression analysis. The limits of these analytical procedures do not allow for the investigation of how the relationship between first-level variables (i.e., student characteristics, or experiences) and the dependent variable may shift in response to changing second-level variables (i.e., institutional characteristics). These concerns do not limit the capacity for the chosen analytical procedures to describe the relationship between service-learning and particular outcomes; rather, they point toward recommendations for future research.

\section{Findings and Discussion}

This discussion of the study findings are organized into two sections related to the corresponding research questions. The first section examines latent outcome constructs related to the service-learning experiences of LIFG Participants within the national, longitudinal dataset. Comparisons are also examined within the overall sample of service-learning participants. The second section answers the second research question by exploring both strands of data. This includes the results of multiple regression analyses examining the relationship between participation in service-learning courses and each of the three outcome variables (cumulative GPA, civic awareness, and cognitive diversity), as well as the emergent themes resulting from the participant interviews.

\section{Latent Constructs}

Exploratory factor analysis was performed to investigate the presence of latent constructs for the study population of LIFG college students. In an effort to allow for unanticipated latent constructs, each variable identified as an outcome via the study's integrated conceptual and theoretical model was utilized in this analysis. Principle axis factoring was chosen for its ability to analyze the data structure focusing on shared variance within a set of variables to produce factors that represent latent constructs (Warner, 2013). Additionally, varimax rotation was selected to maximize the sum of variances of the squared loadings and thereby present a simplified factor structure (Tabachnick \& Fiddell, 2007). Analysis of the resulting scree plot indicated the emergence of one, four-item construct with significant internal consistency $(\alpha=0.814)$. It should be noted that though this analysis indicated high inter-correlation of these items, the items did not necessarily represent a unidimensional construct (Gardner, 1995). The following is a list of the variables included in the EFA:

- $\mathrm{CSS}_{3}$ Cumulative

3 Variables with the prefix "CSS" refer to matched variables from HERI's College Senior Survey. 
- College GPA

- CSS Academic Self-Concept Score

- CSS Social Agency Score

- CSS Academic Disengagement Score

- Growth in knowledge of people from different races/cultures

- Growth in analytical and problem-solving skills ]CSS Social Self-Concept Score

- Growth in ability to think critically

- Growth in ability to get along with people of different races/cultures

- Future plans to participate in volunteer work

- Future plans to participate in a community service organization

- View: Same sex couples should have the right to legal marital status

- View: Realistically, an individual can do little to bring about changes in our society

- View: Colleges should prohibit racist/sexist speech on campus

- View: Racial discrimination is no longer a major problem in America

- View: Affirmative action in college admissions should be abolished

- Goal: Improving my understanding of other countries and cultures

Table 5 outlines the weighting for the four items contributing to this scale: change in ability to think critically, change in analytical and problem-solving skills, change in knowledge of people of different races/ethnicities, and change in ability to get along with people from different races/ethnicities. For the purposes of this study, this scale is referred to as the "cognitive diversity scale" in an effort to capture students' self-reported change in their cognitive and diversity skills. Conceptually, this scale is most representative, in theory, to the term pluralistic orientation (Hurtado, 2007) and the development of critical consciousness (Ginwright \& Commarota, 2002); however, with HERI's recent development and phased inclusion of a "pluralistic orientation scale," the use of that specific scale name has been avoided in an effort to limit confusion of the two scales.4

Table 5. Component Matrix for Cognitive Diversity Scale

\begin{tabular}{lcr}
\hline Items $(\alpha=0.814)$ & Factor Loading & \% of Variance \\
\hline Growth in knowledge of people from different races/cultures & 0.816 & 64.330 \\
$\begin{array}{l}\text { Growth in ability to get along with people of different } \\
\text { races/cultures }\end{array}$ & 0.747 & 20.582 \\
Growth in ability to think critically & 0.834 & 8.862 \\
Growth in analytical and problem-solving skills & 0.809 & 6.227 \\
\hline
\end{tabular}

Whether or not this latent factor represented a uni- or multidimensional construct, it did signify that change in cognitive reasoning skills and in broadening perspectives were deeply connected for the LIFG students in this study. Moreover, this analysis indicated that when growth occurred in one it was likely to also occur in the other. One explanation of this phenomenon is that growth in higher order thinking skills and the knowledge of and ability to get along with people from different races and cultures may have

4 Items constituting the pluralistic orientation scale were not yet included in HERI's 2008 College Senior Survey. 
been mutually reinforcing patterns for LIFG students. Though this factor had a high internal consistency for LIFG students, regression analysis was required to investigate its relationship to service-learning.

\section{Service-Learning Outcomes}

Multiple regression analyses were performed to identify the relationships between participation in service learning for LIFG and GPA, civic awareness, and cognitive diversity. Separate blocked OLS regressions were fit for each of the three outcome variables. Ad hoc analyses were also conducted on the overall sample to provide context and comparison for the results of the analysis of the LIFG student population. Of the three regression analyses performed on LIFG students, participation in service-learning was only a statistically significant predictor for GPA. Five core themes emerged from participant interviews regarding the learning and development that students attributed to their service-learning courses. Two of the themes (critical consciousness and cognitive diversity) related directly to findings within the quantitative results:

- Critical consciousness: Focuses on an individual's ability to understand the world as being situated within complex social and political relationships, with specific awareness of how institutional, historic, and systematic forces limit or promote opportunities for groups of people (Freire, 1973).

- Cognitive diversity: Similar to the factor found in the quantitative analysis, this theme involves a broadening of perspectives related to diversity and to increases in cognitive development.

The following subsections discuss in detail these related outcomes along with findings integrated from both strands of data.

\section{College GPA}

Table 6 includes the results of the OLS regression predicting college GPA. Students' pre-college characteristics accounted for the largest amount of variance in the final model $(11.2 \%)$, including three significant $(p \leq 0.05)$ variables: Black $(\mathrm{B}=-0.883)$, Hispanic $(\mathrm{B}=-0.897)$, and Multiracial $(\mathrm{B}=-0.925)$. Students' high school GPA $(\mathrm{B}=0.343)$ was a highly significant $(p \leq 0.001)$ positive predictor of college GPA, whereas high school participation in service-learning courses had a somewhat significant negative relationship with college GPA $(\mathrm{B}=-0.265 ; p \leq 0.10)$ when all other variables were held constant. While none of the student college characteristics was significant, one institutional characteristic, institutional selectivity $(\mathrm{B}=-0.002)$, had a somewhat significant $(p \leq 0.10)$ negative relationship with college GPA. Finally, service-learning participation had a significant positive $(\mathrm{B}=0.496 ; p \leq 0.05)$ relationship with GPA when all other variables were held constant. While the full model accounted for $24.5 \%$ of the variance in college GPA, the inclusion of service-learning in the model increased the overall $\mathrm{R}^{2}$ by 4.1 percentage points. Such a percentage of variation explained by a single item is large; together, the other 18 independent variables together accounted for only $19.2 \%$ of the variance in GPA.

Some evidence suggested that the sample LIFG Participants, as a whole, were somewhat more academically prepared than the LIFG's who did not participate in service-learning. This was an important consideration because it could have meant that service-learning participation was a mediating variable between pre-college academic preparation and college GPA. To account for this possibility, high school GPA was controlled for in the regression. The final model indicated that participation in service-learning courses still had a statistically significant positive relationship with college GPA even when other variables (e.g., high school GPA) were held constant. In other words, participation in service-learning had a positive influence upon college GPA above and beyond any influence of high school GPA. It should also be noted that Black $(\mathrm{B}=-0.883)$, Hispanic $(\mathrm{B}=-0.897)$, and Multiracial $(\mathrm{B}=-0.925)$ race and ethnicity descriptors were significant $(p \leq 0.05)$ negative predictors of college GPA. This finding 
indicated that even when financial capital (low-income), cultural capital (first-generation), and academic preparation were held constant, there appeared to be systemic racial inequities that occurred during the college experience, resulting in disproportionally lower GPA attainment for these subpopulations. This finding was consistent with previous research by Engle and Tinto (2008) concluding that lower performance and persistence rates of LIFG students are as likely the result of the experiences they have in college as pre-college characteristics. 
Table 6. Results for Blocked Regression Model Predicting College GPA for LIFG Students

\begin{tabular}{|c|c|c|c|c|c|c|c|c|c|c|}
\hline \multirow{2}{*}{ Variables } & \multicolumn{2}{|c|}{ M1 } & \multicolumn{2}{|c|}{ M2 } & \multicolumn{2}{|c|}{ M3 } & \multicolumn{2}{|c|}{ M4 } & \multicolumn{2}{|c|}{ M5 } \\
\hline & $\mathrm{B}$ & $p$ & B & $p$ & B & $p$ & B & $p$ & $\mathbf{B}$ & $p$ \\
\hline \multicolumn{11}{|l|}{ Student Pre-College Characteristics } \\
\hline (Constant) & 6.080 & 0.000 & 3.892 & 0.000 & 2.895 & 0.030 & 5.016 & 0.002 & 4.859 & 0.003 \\
\hline Male & -0.223 & 0.286 & -0.265 & 0.201 & -0.220 & 0.290 & -0.195 & 0.348 & -0.183 & 0.370 \\
\hline Asian & -0.300 & 0.433 & -0.391 & 0.291 & -0.332 & 0.369 & -0.268 & 0.471 & -0.131 & 0.723 \\
\hline Black & -0.960 & $.020 * *$ & -0.968 & $.014 * *$ & -0.948 & $0.017 * *$ & -0.883 & $0.027 * *$ & -0.883 & $0.026 * *$ \\
\hline Hispanic & -1.087 & $.002 * *$ & -1.067 & $.001 * * *$ & -0.989 & $0.003 * *$ & -0.922 & $0.005 * *$ & -0.897 & $0.006 * *$ \\
\hline Other Race/Ethnicity & -0.607 & 0.252 & -0.403 & 0.435 & -0.201 & 0.697 & -0.173 & 0.736 & -0.169 & 0.741 \\
\hline Multicultural & -1.175 & $.009 * *$ & -1.085 & $.014 * *$ & -0.921 & $0.028 * *$ & -0.909 & $0.030 * *$ & -0.925 & $0.024 * *$ \\
\hline TFS View: Racial discrimination is no longer a major problem in America & 0.126 & 0.659 & 0.222 & 0.441 & 0.290 & 0.329 & 0.276 & 0.360 & 0.241 & 0.416 \\
\hline $\begin{array}{l}\text { TFS View: Realistically, an individual can do little to bring about changes } \\
\text { in our society }\end{array}$ & 0.115 & 0.578 & 0.159 & 0.419 & 0.114 & 0.563 & 0.087 & 0.656 & 0.104 & 0.591 \\
\hline TFS View: Colleges should prohibit racist/sexist speech on campus & -0.179 & 0.347 & -0.124 & 0.501 & -0.129 & 0.487 & -0.190 & 0.312 & -0.216 & 0.248 \\
\hline TFS View: Same-sex couples should have the right to legal marital status & -0.040 & 0.863 & 0.073 & 0.731 & 0.149 & 0.493 & 0.157 & 0.469 & 0.129 & 0.543 \\
\hline TFS View: Affirmative action in college admission should be abolished & 0.112 & 0.610 & 0.077 & 0.716 & 0.118 & 0.582 & 0.153 & 0.471 & 0.186 & 0.376 \\
\hline \multicolumn{11}{|l|}{ Student Pre-College Experiences } \\
\hline High School GPA & & & 0.315 & $.000 * * *$ & 0.312 & $0.000 * * *$ & 0.325 & $0.000 * * *$ & 0.337 & $0.000 * * *$ \\
\hline High School Service-Learning Participation & & & -0.275 & $.044 * *$ & -0.280 & $0.049 * *$ & -0.271 & $0.056 *$ & -0.265 & 0.061* \\
\hline High School Community Service Participation & & & 0.121 & 0.395 & 0.103 & 0.479 & 0.105 & 0.473 & 0.040 & 0.785 \\
\hline Community Service Required in High School & & & 0.150 & 0.494 & 0.155 & 0.478 & 0.131 & 0.555 & 0.101 & 0.647 \\
\hline \multicolumn{11}{|l|}{ Student College Characteristics } \\
\hline Major: Math and Sciences & & & & & 0.292 & 0.263 & 0.258 & 0.333 & 0.244 & 0.353 \\
\hline Major: Social Sciences & & & & & 0.182 & 0.480 & 0.178 & 0.488 & 0.069 & 0.788 \\
\hline Major: Pre-Professional & & & & & 0.590 & 0.044 & 0.444 & 0.139 & 0.382 & 0.202 \\
\hline Major: Other & & & & & -0.304 & 0.379 & -0.382 & 0.273 & -0.372 & 0.280 \\
\hline Full-Time Enrollment & & & & & 0.752 & 0.528 & 0.819 & 0.492 & 0.762 & 0.532 \\
\hline \multicolumn{11}{|l|}{ Institutional Characteristics } \\
\hline Public Institution & & & & & & & -0.376 & 0.096 & -0.336 & 0.132 \\
\hline Institutional Selectivity & & & & & & & -0.002 & 0.076 & -0.002 & $0.090 *$ \\
\hline \multicolumn{11}{|l|}{ Service-Learning } \\
\hline Participation in Service-Learning Course(s) & & & & & & & & & 0.496 & $0.010 * *$ \\
\hline Change in $\mathrm{R}^{2}$ & & 0.112 & & 0.060 & & 0.014 & & 0.018 & & 0.041 \\
\hline$<0 \quad \mathrm{R}^{2}$ & & 0.112 & & 0.172 & & 0.186 & & 0.204 & & 0.245 \\
\hline
\end{tabular}

Note. * Significant at $p \quad .10 . * *$ Significant at $p \quad .05 . * * *$ Significant at $p \quad .001$. 
When interview participants were initially asked to share what learning occurred in their servicelearning courses, each was quick to respond that they learned a great deal more from these courses than their average courses. When asked to explain this perception, all participant indicated that they had learned the course content at a deeper level because of the "hands-on" or "real-world" context of their respective service-learning course. About half of the participants noted that their increased learning was also related to their own level of caring; in other words their level of psychological investment. Joe described an unexpected - to him-synthesis resulting from his course on British culture: His exposure to British culture illuminated, for him, the ways in which some of society's systematic forces work within civil rights movements. Joe went on to explain that his service experience allowed him to better understand similar forces within the American civil rights movement. Interestingly, though each interview participant claimed unequivocally that they learned more in their service-learning course than in other courses, when asked to share details about that learning, each participant began to describe outcomes that were more affective in nature.

\section{Civic awareness and critical consciousness}

Blocked OLS regression analysis for the LIFG student population predicting CIRP civic awareness scores indicated that none of the independent variables were significant predictors within the any of the models (see Appendix A, Table A2). While this finding was atypical, it was indicative of limited variation in the dependent variable among the sample. Additionally, an ANOVA indicated that no significant difference existed between groups related to these outcomes. This finding suggests that the pre-college characteristic of being an LIFG student may be a mediating variable for civic awareness. In other words, it could be that there is something about being a low-income and/or first-generation student that eliminates the amount of variance in the civic awareness score. Previous literature has suggested that low-income and first-generation students are less likely to be civically aware or civically engaged (Burns, Scholzman, \& Verba, 2001; Nie, Junn, \& Stehlik-Barry, 1996; Verba, Scholzman, \& Brady, 1995); therefore, it is likely that being low-income and/or first-generation would limit, or have a suppression effect upon, the variation in this outcome for the entire subgroup. It may also be the case that the social desirability of these traits may increase students' self-reporting. Though the quantitative data did not indicate much variation between LIFG Participants and LIFG Nonparticipants in civic awareness scores, interview participants clearly demonstrated development within critical consciousness - a closely related outcome.

Consistent with the literature on the affective outcomes of service-learning (Ginwright \& Commarota, 2002), several participants described a growing sense of the complex social and political relationships that exert forces on the opportunities of particular groups of people-in other words, critical consciousness. Responding to a question about how his interaction with community partners may have differed from the experiences of classmates who were not from similar backgrounds as him, Adam, shared:

Just, a lot of people in our classes and stuff haven't come from lower-income backgrounds and so they don't always understand people as well and sometimes there's this ... I don't know, in our classes we go over social justice a lot, so much folks have a reasonable idea of it - but I guess for me it is more of a practical experience, just the basic understanding that just because somebody's poor that doesn't mean they are this lazy or drug-addicted stereotype.

As Adam's comment makes clear, in light of the social justice emphasis which he felt pervaded his major, his personal experiences were still practically shaped in relation to his self-identity. His personal relationship with poverty cultivated a more critical questioning of commonly accepted stereotypes, especially as they related to his service-learning experiences engaging with housing issues in impoverished communities.

The ideology of perceiving those being served as community partners is deeply linked to a social justice movement within service-learning curricula and research advocated by scholars like Ginwright and 
Commarota (2002). Their critique of service-learning highlighted the pedagogy's ability to engender a critical consciousness within youth, especially those from "oppressed" backgrounds. Within the last 15 years, several researchers have utilized the term critical service-learning to describe service-learning experiences that employ a social justice perspective (Rhoads, 1997; Rice \& Pollack, 2000; Rosenberger, 2000). In 2008, Mitchell formalized the term by advancing a critical model of service-learning and comparing it to traditional views of service-learning. In her model, Mitchell placed equal emphasis on student outcomes and social change, arguing that, together, these goals promote the development of critical consciousness within students:

Critical service-learning pedagogy fosters a critical consciousness, allowing students to combine action and reflection in classroom and community to examine both the historical precedents of the social problems addressed in their service placements and the impact of their personal action/inaction in maintaining and transforming those problems. This analysis allows students to connect their own lives to the lives of those with whom they work in their service experiences. (p. 54)

The cultivation of students' critical consciousness requires a service-learning curriculum whereby faculty validate those being served as active contributors and co-educators in the service-learning experience-hence, the commonly used term community partners.

A critical view of service-learning is essential to the validation process of community partners, especially for LIFG students who often identify personally with the community partners - as it offers students the opportunity to analyze systems of oppression and question stereotypes that may characterize the poor or marginalized as lazy, stupid, or deficient in some way. Adam went on to share that because of his program faculty's commitment to social justice, it was very easy for him to engage with his classmates around the propagation of negative stereotypes. Similarly, Joe described an unexpected learning outcome - that is, a deeper understanding of the systematic forces involved in the American civil rights movement - resulting from his service-learning course. Joe explained that this was not a specific learning outcome for the course but rather a result of the process of analyzing the British civil rights movement; however, he also conceded that perhaps his professor intended these connections to be made by students. As Mitchell (2008) argued, a critical model of service-learning allows students to develop critical consciousness through examining the historical precedents of social issues and allowing them to reflect on the pragmatic effects their actions or inactions have on maintaining or transforming those issues. It is through this humanizing process that students are able to connect their own lives to those with whom they are interacting.

\section{Cognitive diversity}

Similar to the previous findings regarding civic awareness, a blocked OLS regression predicting cognitive diversity scores for LIFG students resulted with only one significant $(p \leq 0.05)$ variable: the first-year view that affirmative action in college admission should be abolished $(B=-0.487$; see Appendix $A$, Table A3). The significant negative relationship this first-year view had upon the cognitive diversity scores of LIFG seniors suggests that cognitive diversity represents a form of critical consciousness held by students. This finding also suggests the lasting effect that pre-college beliefs or values can have upon college outcomes.

Once again, for LIFG students, service-learning participation was not a significant predictor of cognitive diversity scores. As was the case with civic awareness, the lack of significance for the overwhelming majority of variables in the model suggests limited variation in the dependent variable for LIFG students. Interestingly, this was one of the most prevalent learning outcomes that emerged from participant interviews. This divergence in findings suggests several possibilities discussed below.

While not part of the original conceptualization of the study, several ad hoc tests were conducted in response to the initial finding that service-learning was not a significant predictor for cognitive diversity 
scores. Regression analysis of the individual survey items that make up the cognitive diversity scale indicated that service-learning was not a significant predictor of these scores. This may have indicated that service-learning did not increase exposure to diversity and cognitive development for LIFG students - a contrast with prior research suggesting generally that service-learning experiences contribute to these outcomes (Batchelder \& Root, 1994; Eyler \& Giles, 1999; Osborne, Hammerich, Hensley, 1998). Another, and much more likely, hypothesis is that LIFG students perceived growth in these areas as a result of their overall college experiences such that little variance existed between LIFG Participants and LIFG Nonparticipants in relation to these outcome variables. Since each of these items were self-reported by college seniors just prior to graduation, this may have simply been a limitation of the data. To investigate the plausibility of this hypothesis, the individual items making up the cognitive diversity scale were investigated. Descriptive analysis showed that most students rated themselves high for each individual survey item; concordantly, there was very little variation present, explaining why almost no independent variables were significant predictors in either of the regression models.

College seniors' perception that they have grown in critical thinking, analytical problem solving, and knowledge of and ability to get along with people from different races and ethnicities while in college are commonly expected and stated goals of higher education institutions, as well as society at large. Thus, seniors' perception that they have achieved these learning outcomes is not surprising, regardless of whether or not actual growth has occurred. Additionally, research indicates that students may have difficulties self-assessing subjective measures (Gonyea, 2005; Porter, 2011). As such, self-assessment of learning outcomes may be conflated with perceptions of satisfaction (Eyler, 2000). Whereas the other measures ask students to assess their skills and growth, the GPA item asks students to report a more objective figure. By comparison, regression analyses of CIRP's civic awareness scores and of the cognitive diversity scores conducted for the larger overall sample of college student resulted in models in which service-learning was a highly significant $(p \leq 0.001)$ positive predictor of both of these outcomes. The large size of the overall sample allowed for increased variation and likely allowed for the nuance to be captured. This suggests that a larger sample of LIFG students might allow for a similar effect to be identified.

Despite some inconclusive findings in the quantitative data, interview participants described deep learning and growth in broadening their perspectives on diversity as a result of their service-learning experiences. This broadening was accompanied by a description of growth in higher order cognitive skills, whereby participants were able to analyze and even maintain multiple perspectives. Participants articulated a deepening understanding of both human similarities and differences through their interactions with classmates and community partners during their service experiences. When Joe was asked what he learned from his service-learning course, he began by describing content knowledge from his course on European culture; however, his description eventually gave way to comments about his developing view of people:

I've learned that as different as people, or a group of people, may seem or be, like, there's actually plenty of commonalities between us considering the fact that we're all people. And so, surface differences are not as important.... And so, um, just being able to learn about other cultures, seeing what's different, seeing what's the same, and being able to adjust to what's different and not just shooting it down, avoiding it, ignoring it because it's different - embracing difference and stuff.

Joe described a broadening of perspective that occurred through his interactions with other people. This interaction had a dual effect upon Joe's understanding of people as simultaneously possessing both great variations and great similarities. Joe described his experience as one that cultivated greater awareness of the diversity in the world, especially among cultures; yet, this awareness and appreciation of diversity was, at the same time, layered with a growing understanding of the similarities that also exist among all people - essential humanness that unites individuals through the richness of diversity. 
Joe's perspectives were shared as expressions of the realistic complexity of the world. Bob articulated a similar growing understanding:

Getting to familiarize yourself with people from different cultures, learning about what happens in those cultures and how you can relate them to your own. I mean we're all different but we all have similarities too, and so it's finding that common ground so we don't have these struggling situations, and I think that's a great thing that a lot of people need.

I've realized that I can actually challenge myself to be more accepting of somebody I don't really get along with. And that kind of amazed me. Because I've always been in that mindset of, like, "I either dislike you or I like you." Like, there's no middle ground. And I'm learning, like, there can be a middle ground. There really has to be a middle ground because if not, you know, what's the outcome of it? And it's either gonna be a positive or a negative. And it should always be a positive. So, just learning that I can be more challenging of myself and accepting of the other person's standpoint.

Bob spoke of his growing understanding as the catalyst for a surprising discovery - that he was able to challenge himself to find common ground with others while accepting their difference. This ability to consider multiple perspectives in an effort to constitute a more just society is described by Kohlberg (as cited in Evans, Forney, Guido, Patton, \& Renn, 2009) as postconventional morality. According to Kohlberg's theory, postconventional morality represents the third and final level of moral development, where multiple perspectives are given voice and where principled rationality serves as the basis for determining what is most just. Joe articulated a movement beyond dualist thought (i.e., this or that; like or dislike) toward pluralism, whereby multiple perspectives and even contradictions may co-exist. Joe's assertion that difference should be embraced connotes a realization that difference does not have to be prioritized into right and wrong, but instead can simply be different. A second phase of Kohlberg's postconventional morality is the ability to recognize a plurality of perspectives while maintaining a commitment to a particular perspective based upon a logically stated rationale. Bob articulated such a commitment in light of broadening of perspectives when he described that what is best is determined by weighing the possible outcomes and choosing what is best for all parties involved. In this case, Bob employed utilitarian ethics - a rationalization of the greatest overall "good" - to evaluate multiple perspectives.

\section{Conclusions}

Two primary conclusions that can be drawn from the synthesis of the quantitative and qualitative findings of this study to inform the understanding of the potential experiences and outcomes of LIFG college students who participate in service-learning courses. These conclusions align with the research questions and analyses regarding the outcomes of LIFG students' participation in service-learning.

\section{Service-Learning Participation Has a Positive Effect on Academic Outcomes for LIFG Students}

Above and beyond the influence of pre-college characteristics and college experiences, LIFG students' participation in service-learning courses was positively associated with college GPA - perhaps the most indicative and certainly the most common measurement of academic achievement (York, Gibson, \& Rankin, 2015). The persistence of a relationship between participating in service-learning and college GPA, despite including other variables in the model (e.g., race, high school GPA, primary major, and institutional selectivity,) suggests that service-learning is a meaningful activity for LIFG students' academic success. Moreover, the inclusion of this variable increased the model's ability to explain an 
additional $4.1 \%$ of the variation observed in college GPA, illustrating the strength of the relationship between service-learning and college GPA.

In this study, participation in service-learning was also related to the development of several cognitive processes that include higher order skills such as critical thinking, analytical problem solving, and the evaluation of multiple perspectives. The development of these cognitive skills was suggested in the qualitative findings by the emergence of themes related to the cultivation of critical consciousness and cognitive diversity (i.e., the latent construct uncovered in the exploratory factor analysis). As suggested by Astin et al.'s (2000) findings related to the overall student population, participation in service-learning courses for LIFG students encourages increased gains in academic outcomes above and beyond those attributed to other input and experiential variables such as race or major.

\section{Service-Learning Participation Is Positively Related to Affective Outcomes for LIFG Students}

In addition to the positive association that service-learning participation had with learning, LIFG students' participation was also positively associated with the development of several affective outcomes important to student success. Though service-learning participation was not found to be a significant predictor of LIFG students' perception of their cognitive diversity, LIFG Participants in the qualitative phase of the study attributed gains in their understanding of diverse persons and perspectives - part of this study's definition of cognitive diversity - to their service-learning experiences. These qualitative findings supported the hypothesis that the quantitative findings were likely a product of the lack of variation among the responses to the survey items constituting the cognitive diversity scale. Additionally, findings from the qualitative phase of the study suggest that LIFG college students may be able to achieve greater understanding and awareness of the complexities of social, political, and historical forces that can serve to limit the opportunities of particular groups of people (critical consciousness) due to their service-learning experiences. These findings suggest that LIFG students' participation in service-learning courses encourages the development of several affective outcomes that are beneficial to their success.

Both of these conclusions increase the collective understanding around service-learning for LIFG students. Moreover, these conclusions are especially important because they illustrate the positive influence that service-learning pedagogy has upon learning and development. In other words, the findings support the efficacy of service-learning as a pedagogical strategy for increasing the learning and development of students and, in turn, aiding in student success. While the primary findings the two data streams are fairly convergent, there are two places (civic awareness and cognitive diversity) where the findings diverge. For this reason, I hesitate to label their synthesis as "conclusions" since they are, in fact, inconclusive. However, this divergence of results is an important aspect of the ways in which the next two conclusions can increase the understanding of this phenomenon. These divergences highlight the challenges related to self-reported measures of cognitive growth or diversity skills, particularly for students who enter college with experiences that inform their development differently than the historically "traditional" student population.

\section{Service-Learning Participation Has a Mixed Impact on the Development of Civic Awareness for LIFG Students}

Results from the quantitative phase of this study indicated that service-learning participation was not a significant predictor of growth in the CIRP civic awareness scale. Yet, results from the qualitative phase of this study indicated that, for LIFG students, participation in service-learning helped to cultivate critical consciousness and a view of service as a reciprocal transaction important for the betterment of all partners involved. This divergence supports Battistoni's (2013) argument concerning the inadequacy of current research - specifically concerning the availability of valid measurements - on civic learning outcomes, which should be parsed as several incredibly rich constructs such as civic awareness, civic engagement, and even civic beliefs. This divergence of findings confirms the complexity of these constructs and 
suggests that while service-learning participation may not have a significant relationship with the specific CIRP civic awareness scale, participation does impact the development of critical consciousness and a reciprocal view of service-which I argue are aspects of civic learning consistent with the conception of participatory democracy (Barber, 1984, 1992; Freire, 1973).5 Furthermore, the mix of these results is consistent with a previous study that utilized the same survey in 2004, and that found that service-learning did not contribute to most civic values or goals for the overall college population, with the exception of "commitment to political/social change" (Vogelgesang \& Pryor, 2009). This previous study adds weight to the recommendation to assess the influence of service-learning participation upon a variety of civic outcomes individually.

\section{Service-Learning Participation Has a Mixed Impact upon the Development of Cognitive and Diversity Outcomes for LIFG Students}

Results from the quantitative phase of this study indicated that service-learning participation was not a significant predictor of growth in the latent cognitive diversity scale. Yet, results from the qualitative phase of the study suggested that participation in service-learning helped to broaden LIFG students' perspectives related to diversity issues and was accompanied by growth in higher order cognitive skills. Further investigation in the quantitative phase revealed that LIFG students, regardless of their servicelearning participation, tended to self-report high levels of growth on the individual items that comprised this scale. 6

\section{Implications}

\section{Implications for Practice}

The findings and conclusions of this study are perhaps most clear and applicable for practice given the pragmatic nature of pedagogical experience. The conclusion that service-learning participation has a positive impact upon academic and affective outcomes for LIFG students indicates that service-learning is an effective pedagogy for increasing LIFG students' success and, in turn, their persistence-an implication consistent with suggestions from past research (Bringle, Hatcher, \& Muthiah, 2010; Yeh, 2010). Institutions seeking to increase the success of their low-income or first-generation students should consider specific ways to provide well-integrated service-learning experiences into students' curricula.

By "well-integrated," I specifically refer to service-learning experiences in which faculty are equipped to engage students in reflective discourse around issues of difference and sameness-issues this study has shown students are likely to encounter. Given the importance of critical theory in aiding the critical consciousness and biculturalism of LIFG students, faculty and service-learning administrators should seek to utilize critical models of service-learning (Ginwright \& Commarota, 2002; Mitchell, 2008), which emphasize true community partnerships and, in so doing, help students navigate issues of power, privilege, and systematic oppression. While many faculty may advocate for the use of these philosophical traditions for their ability to cultivate critical consciousness, this study's findings indicate that their use in service-learning experiences is important specifically for LIFG students' encounters with "self" in their interactions with community partners. Critical models of service-learning allow LIFG students to affirm the value of community partners in the learning experience, reinforcing affirmations of self, while also promoting their self-identities as agents for social change (Freire, 1973). Furthermore,

5 Battistoni (2013) argued that participatory democracy has gained increasing acceptance within the realm of service-learning research as a conceptual framework whereby participation in service-learning cultivates a person's self-identity as a civic agent who is able to effect change in communities or address social problems.

6 The individual items that make up this scale include: (1) change in knowledge of people from different races and cultures, (2) change in ability to get along with people of different races and cultures, (3) change in ability to think critically, and (4) change in analytical and problem-solving skills. 
these results indicate that faculty who utilize service-learning pedagogies are uniquely positioned to act as cultural agents for LIFG students (Kuh \& Love, 2000). Institutions should explore ways to provide professional development opportunities for faculty that focus on integrating a critical model of servicelearning and facilitating reflective discourse.

Another implication for practice focuses on methods for increasing student participation in servicelearning courses. The findings from both phases of this study indicated that prior service experiences (especially high school community service opportunities) significantly contributed to college participation. For many LIFG students, opportunities to participate in high school community service may be decreased by limited financial or cultural capital. K-12 administrators and faculty should explore avenues for providing in- and out-of-school service experiences for these students. Higher education professionals should also cultivate outreach and extension opportunities to partner with secondary educators, especially those from high schools with large low-income populations, as part of service experiences.

\section{Implications for Policy}

Implications of this study for policy are especially important considering current reductions in funding for service-learning programs at the federal level. In April of 2011, the federal government made several funding cuts to national community and service-learning initiatives. Learn and Serve America, a granting agency of the Corporation for National and Community Service that serves elementary through postsecondary institutions, had its entire 2011 budget cut (\$39.5 million). Similarly, AmeriCorps' budget was reduced by $\$ 22.5$ million. The evidence from this study regarding the efficacy of service-learning pedagogies for increasing the success of LIFG students in higher education constitutes an argument to restore and/or advance appropriations for service agencies. Additionally, the virtuous cycle, or Matthew effect (Stanovich, 1986), of service participation illustrates the importance of such agencies in advancing early integration of service opportunities for K-12 institutions, especially through grants that provide resources for Title IX schools. While these funding implications focus on the pragmatic reality of providing service opportunities in educational settings, these opportunities connect to the much broader national goals of increasing the access and persistence of diverse segments of America's population.

At the institutional policy level, this study's conclusions support efforts by faculty and administrators to institutionalize service-learning in both organizational structure and institutional commitments. While many institutions highlight the influence that service-learning courses have on civic awareness and engagement, Furco and Holland (2013) noted the importance of emphasizing the influence that servicelearning participation has on achieving the academic mission of the institution. The conclusions of this study indicate that for LIFG students, service-learning participation has a greater influence on academic outcomes than civic awareness. Kecskes (2013) also argued that administrators seeking to increase the use of service-learning pedagogies by faculty should focus on institutionalization efforts at the academic departmental level, with the locus of change most often centering on these "engaged departments." However, heeding Butin's (2006) warning, such institutionalization should be undertaken with the understanding that service-learning pedagogies will result in varying outcomes for various student groups and that assessment efforts should account for such variation to fully capture the impact of such experiences. Finally, institutional policies should reflect institutional goals for increased commitment to service-learning. For example, promotion and tenure policies should reward the increased time and skill involved in teaching service-learning courses.

\section{Implications for Research}

This study was designed by utilizing and advancing a layered theoretical and conceptual framework. This layered approach extended and contextualized Astin's (1991) input-environment-output model and Dewey's (1938) principles of interaction and continuity, providing a model explaining the relationship of students' backgrounds and college experiences (e.g., service-learning) with student outcomes. As such, this model helps explain "how" and "why" the service-learning curriculum can be an effective 
pedagogical strategy for increasing the success of LIFG college students. I utilized this layered model to advance a theoretical and conceptual rationale for the study's research questions, asserting primarily that LIFG student's background characteristics would affect both the ways in which they experienced servicelearning courses and the outcomes of that experience.

The findings of this study suggested that LIFG students' experiences in service-learning are qualitatively different and result in some alternative - though equally positive-outcomes compared with those associated with participation for the overall student population. Future studies evaluating the efficacy of learning experiences for LIFG students should use this layered model in their designs, especially in regards to investigating outcome factors particular to this student group. Research that only investigates outcomes related to a particular pedagogical strategy for the overall student population may in fact invalidate that pedagogy without adequately capturing outcomes that are specifically related to the experience of LIFG students. Naturally, these implications directly inform future research on servicelearning and, more broadly, LIFG student success. Much of this research will rely on large-scale datasets due to the specific nature of LIFG students' demographic criteria. Therefore, a final implication of this study relates to the availability of student-level data on service-learning experiences. Large-scale data sources, namely those that investigate the relationship between college student experiences and outcomes, should incorporate survey questions specific to service-learning participation (clearly defined and separated from community service). Moreover, this study suggests that quantitative instruments used to assess constructs related to civic awareness, diversity skills, or cognitive abilities may not be sufficiently valid for populations of low-income and/or first-generation college students. The layered theoretical and conceptual model advanced by this study prescribes measurements that account for the moderated and independent effect that input characteristics (such as being LIFG) have upon related outcomes. These research implications will provide important data necessary for future research on this topic.

\section{Summary}

Future research on service-learning can only strengthen our ability to employ the pedagogical strategy for the benefit of student success. This study aimed to increase the understanding of the outcomes and experiences related to participation in service-learning for low-income, first-generation college students, a topic that has been unaddressed by the current research literature. Using multiple data streams, the study found that low-income, first-generation students participate in service-learning at similar rates as the overall population and that participation is significantly related to past service participation and to a combination of internal and external motivations. The study also found that participation in servicelearning courses was positively related to increases in college GPA, even after controlling for background characteristics and pre-college experiences. Moreover, the study found that participation resulted in cultivation of several intended and unintended learning and developmental outcomes, such as critical consciousness, cognitive diversity, and career acculturation. The findings disproved many previously held assumptions about low-income, first-generation students' participation in service-learning-for instance, that minorities are less likely to participate in service-learning courses. These findings have implications for practice, institutional and federal policy, and research. The study's conclusions therefore accomplish the task of increasing the understanding of low-income, first-generation students' servicelearning participation while also enumerating several directions for future inquiry. Most importantly, this study strongly supported the conclusion that participation in service-learning courses aids in the development of both academic and affective outcomes related to the success of low-income, firstgeneration college students.

\section{Author Note}

Travis T. York, Student Success, Research, and Policy, Association of Public and Land-grant Universities. 


\section{Correspondence}

Correspondence regarding this article should be addressed to Travis T. York, Ph.D., Director of Student Success, Research, \& Policy, Association of Public \& Land-grant Universities, 1307 New York Avenue, NW, Suite 400, Washington, DC 20005. Phone: (202) 478-6047. E-mail: tyork@aplu.org

\section{References}

Andolina, M. W., Jenkins, K., Zukin, C., \& Keeter, S. (2003). Habits from home, lessons from school: Influences on youth civic engagement. Political Science and Politics, 36(2), 275-280.

Astin, A. W. (1991). Assessment for excellence: The philosophy and practice of assessment and evaluation in Higher Education. New York: Macmillan.

Astin, A. W., \& Sax, L. J. (1998). How undergraduates are affected by service participation. Journal of College Student Development, 39(3), 251-263

Astin, A. W., Vogelgesang, L. J., Ikeda, E. K., \& Yee, J. A. (2000). How service learning affects students. Los Angeles, CA: UCLA, Higher Education Research Institute.

Barber, B. (1984). Strong democracy. Berkeley, CA: University of California

Barber, B. (1992). An aristocracy of everyone: The politics of education and the future of America. New York, NY: Ballantine.

Batchelder, T. H., \& Root, S. (1994). Effects of an undergraduate program to integrate academic learning and service: Cognitive, prosocial cognitive, and identity outcomes. Journal of Adolescence, 17, 341355.

Benson, L., Harkavy, I., \& Puckett, J. (2007). Dewey's dream: Universities and democracies in an age of education reform. Philadelphia, PA: Temple University Press.

Boss, J. A. (1994). The effect of community service on the moral development of college ethics students. Journal of Moral Development, 23(2), 183-198.

Bogdan, R. C., \& Bkilen, S. K. (2007). Qualitative research for education: An introduction to theory and methods $\left(5^{\text {th }}\right.$ Edition). Boston, MA: Pearson Education, Inc.

Bringle, R. G., Hatcher, J. A., \& Muthiah, R. N. (2010). The role of service-learning on the retention of first-year students to second year. Michigan Journal of Community Service Learning, 17(2), 38-49.

Bryman, A. (2006). Integrating quantitative and qualitative research: How is it done? Qualitative Research, 6(1), 97-113. doi:10.1177/1468794106058877

Burns, N., Schlozman, K. L., \& Verba, S. (2001). The private roots of public action: Gender, equality, and political participation. Cambridge, MA: Harvard University Press.

Butin, D. W. (2006). The limits of service-learning in higher education. Review of Higher Education, 29(4), 473-498. doi:10.1353/rhe.2006.0025

Campus Compact. (2010). 2009 annual membership survey results: Executive summary. Boston, MA: Campus Compact.

Campus Compact. (2011). 2010 annual membership survey results: Executive summary. Boston, MA: Campus Compact.

Campus Compact. (2012). 2012 Annual membership survey results: Executive summary. Boston, MA: Campus Compact.

Celio, C. I., Durlak, J., \& Dymnicki, A. (2011). A meta-analysis of the impact of service-learning on students. Journal of Experiential Education, 34(2), 164-181. doi:10.5193/JEE34.2.164

Choy, S. P. (2000). Low-income students: Who they are and how they pay for their education (NCES 2000-169). Washington, DC: U.S. Department of Education, Office of Educational Research and Improvement.

Choy, S. P. (2001). Students whose parents did not go to college: Postsecondary access, persistence, and attainment (NCES 2001-126). Washington, DC: U.S. Department of Education, Office of Educational Research and Improvement. 
Choy, S. P. (2003). How families of low-and middle-income undergraduates pay for college: Full-Time dependent students in 1999-2000 (NCES 2003-162). Washington, DC: U.S. Department of Education, Office of Educational Research and Improvement.

Corporation for National and Community Service. (2008). Learn and Serve America performance report 2006-2007. Washington, DC: U.S. Department of Education, Office of Research and Policy Development.

Creswell, J., Plano Clark, V. (2011) Designing and conducting mixed-methods research (2 ${ }^{\text {nd }}$ Ed.). Los Angeles, CA: Sage Publications.

Creswell, J. (2003). Research design: Qualitative, quantitative, and mixed methods approaches ( $2^{\text {nd }}$ Edition). Thousand Oaks, CA: Sage.

Dewey, J. (1938). Experience and education. New York, NY: Touchstone.

Engle, J., \& Tinto, V. (2008). Moving beyond access: College success for low-income, first-generation students. Washington, DC: Pell Institute for the Study of Opportunity in Higher Education. Retrieved from http://www.eric.ed.gov/ERICWebPortal/ recordDetail? accno $=$ ED504448

Evans, N. J., Forney, D. S., Guido, F. M., Patton, L. D., \& Renn, K. A. (2009). Student development in college: Theory, research, and practice. San Francisco, CA: Jossey-Bass.

Eyler, J. S., \& Giles, D. E., Jr. (1999). Where's the learning in service-learning? San Francisco, CA: Jossey-Bass.

Eyler, J. S. (2000). What do we most need to know about the impact of service learning on student learning? [Special issue]. Michigan Journal of Community Service Learning, Fall, 11-17.

Eyler, J. S., Giles, D. E., Jr., Stenson, C. M., \& Gray, C. J. (2001). At a glance: What we know about the effects of service-learning on college students, faculty, institutions and communities, 1993- $2000\left(3^{\text {rd }}\right.$ Edition). Washington, DC: Corporation for National Service \& Learn and Serve America National Service Learning Clearinghouse.

Forsyth, A., \& Furlong, A. (2003). Losing out?: Socioeconomic disadvantage and experience in further and higher education. Bristol, UK: The Policy Press.

Freire, Paulo (1973). Education for critical consciousness, (1st American Edition). A Continuum book. New York: Seabury Press, 1973.

Furco, A., \& Holland, B. A. (2013). Improving research on service learning institutionalization through attention to theories of organizational change. In P. Clayton, R. Bringle, \& J. Hatcher (Eds.), Research on service learning: Conceptual frameworks and assessment (pp. 441-469). Sterling, VA: Stylus.

Gardner, P. L. (1995). Measuring attitudes to science: Unidimensionality and internal consistency revisited. Research in Science Education, 25, 283-289.

Giles, D. E., Jr., \& Eyler, J. S. (1994). The theoretical roots of service-learning in John Dewey: Toward a theory of service-learning. Michigan Journal of Community Service Learning, 1(1), 77-85.

Ginwright, S., \& Cammarota, J. (2002). New terrain in youth development: The promise of a social justice approach. Pedagogies for social change. Social Justice, 29(4), 82-95.

Gonyea, R. M. (2005). Self-reported data in institutional research: Review and recommendations. New Directions for Institutional Research. 73(Fall), 73-89.

Haycock, K. (2006). Promise abandoned: How policy choices and institutional practices restrict college opportunities. Washington, DC: The Educational Trust.

Horn, L. J. (1997). Confronting the odds: Students at risk and the pipeline to higher education. Statistical analysis report (NCES-98-094). Washington, DC: U.S. Department of Education Office of Educational Research and Improvement.

Hurtado, S. (2007). Linking diversity with the educational and civic missions of higher education. Review of Higher Education, 30(2), 185-196. doi:10.1353/rhe.2006.0070

Jacoby, B., \& Associates (1996). Service-learning in higher education: Concepts and practices. San Francisco, CA: Jossey-Bass. 
Kahne, J. E., \& Sporte, S. E. (2008). Developing citizens: The impact of civic learning opportunities on students' commitment to civic participation. American Educational Research Journal, 45(3), 738766. doi:10.3102/0002831208316951

Kecskes, K. (2013). The engaged department: Research, theory, and transformation of the academic unit. In P. Clayton, R. Bringle, \& J. Hatcher (Eds.), Research on service learning: Conceptual frameworks and assessment (pp. 471-503). Sterling, VA: Stylus.

Kuh, G. D., \& Love, P. G. (2000). A cultural perspective on student departure. In J. M. Braxton (Ed.), Reworking the student departure puzzle (pp. 196-212). Nashville, TN: Vanderbilt University Press.

Kuh, G. D., Kinzie, J., Buckley, J. A., Bridges, B. K., \& Hayek, J. C. (2006). What matters to student success: A review of the literature. Commissioned report for the National Symposium on Postsecondary Student Success: Spearheading a Dialog on Student Success. Washington, DC: National Postsecondary Education Cooperative.

Maxwell, J. (2005) Qualitative research design: An interactive approach ( $2^{\text {nd }}$ Edition). Thousand Oaks, CA: Sage.

Merriam, S. B. \& Associates (2002). Qualitative research in practice: Examples for discussion and analysis. San Francisco, CA: Jossey-Bass.

Miller, J. (1994). Linking traditional and service-learning courses: Outcome evaluation utilizing two pedagogically distinct models. Michigan Journal of Community Service Learning, 1(1), 29-36.

Mitchell, T. D. (2008). Traditional vs. critical service-learning: Engaging the literature to differentiate two models. Michigan Journal of Community Service Learning, 14(2), 50-65.

Nie, N. H., Junn, J., \&. Stehlik-Barry, K. (1996). Education and democratic citizenship in America. Chicago: University of Chicago Press.

Osborne, R. E., Hammerich, S., \& Hensley, C. (1998). Student effects of service-learning: Tracking change across a semester. Michigan Journal of Community Service Learning, 5, 5-13.

Pascarella, E. T., \& Terenzini, P. T. (2005). How college affects students: A third decade of research, volume 2. San Francisco: Jossey-Bass.

Perna, L. W. (2002). Precollege outreach programs: Characteristics of programs serving historically underrepresented groups of students. Journal of College Student Development, 43(1), 64-83.

Porter, S. R. (2011). Do college student surveys have any validity? Review of Higher Education, 35(1), 45-76.

Rhoads, R. A. (1997). Community service and higher learning: Explorations of the caring self. Albany, NY: State University of New York Press.

Rendón, L. I. (1994). Validating culturally diverse students: Toward a new model of education. Educational Policy, 16(4), 642-666.

Rice, K., \& Pollack, S. (2000). Developing a critical pedagogy of service learning: Preparing selfreflective, culturally aware, and responsive community participants. In C. O'Grady (Ed.), Integrating service learning and multicultural education in colleges and universities (pp. 115-134). Mahwah, NJ: Lawrence Erlbaum Associates.

Rosenberger, C. (2000). Beyond empathy: Developing critical consciousness through service learning. In C. R. O'Grady (Ed.), Integrating service learning and multi-cultural education in colleges and universities (pp. 23- 43). Mahwah, NJ: Lawrence Erlbaum Associates

Saltmarsh, J., Hartley, M., \& Clayton, P. H. (2009). Democratic engagement white paper. Boston, MA: New England Resource Center for Higher Education.

Sax, L. J., Astin, A. W., \& Astin, H. S. (1996). What were LSAHE impacts on student volunteers? In Gray et al. (Eds.), Evaluation of Learn and Serve America, higher education: First year report. Santa Monica, CA: RAND Corporation.

Stanovich, Keith E. (1986). Matthew effects in reading: Some consequences of individual differences in the acquisition of literacy. Reading Research Quarterly, 21(4), 360-407.

Strage, A. (2000). Service-learning: Enhancing student learning outcomes in a college level lecture course. Michigan Journal of Community Service Learning, 7, 5-13. 
Tabachnick, B. G., \& Fidell, L. S. (2007). Using multivariate statistics (5th ed.). Upper Saddle River, NJ: Pearson Allyn \& Bacon.

Tashakkori, A. \& Teddlie, C. (2010). Handbook of mixed methods in social and behavioral research (2 ${ }^{\text {nd }}$ Edition). Thousand Oaks, CA: Sage.

Verba, S., Schlozman, K. L., \& Brady, H. E. (1995). Voice and equality: Civic voluntarism in American politics. Cambridge, MA: Harvard University Press.

Vogelgesang, L. J., \& Astin, A. W. (2000). Comparing the effects of community service and servicelearning. Michigan Journal of Community Service Learning, 7, 25-34. Retrieved from http://eric.ed.gov/ERICWebPortal/recordDetail?accno=EJ629664

Vogelgesang, L., \& Pryor, J. (2009). Using survey data to assess students' civic outcomes. 2009 IUPUI Symposium, 1-3.

Walpole, M. (2003). Socioeconomic status and college: How SES affects college experiences and outcomes. Review of Higher Education, 27(1), 45-73. doi:10.1353/rhe.2003.0044

Ward, S. (2000, April). Transforming the instructor: Service-learning integrated into a community college curriculum. Paper presented at the annual meeting of the American Educational Research Association, New Orleans, LA.

Warner, R. M. (2013). Applied statistics: From bivariate through multivariate techniques ( ${ }^{\text {nd }}$ Edition). Thousand Oaks, CA: Sage Publications.

Whitt, E. J., Nora, A., Edison, M. I., Terenzini, P. T., \& Pascarella, E. T. (1999). Interactions with peers and objective and self-reported cognitive outcomes across 3 years of college. Journal of College Student Development, 40(1), 61-78.

Yeh, T. (2010). Service-Learning and persistence of low-income, first-generation college students: An exploratory study. Michigan Journal of Community Service, 50-65. Retrieved from http://www.freepatentsonline.com/article/Michigan-Journal-Community-ServiceLearning/255178770.html

Yorio, P.L., \& Ye, F. (2012). A meta-analysis on the effects of service-learning on the social, personal, and cognitive outcomes of learning. Academy of Management Learning and Education, 11(1), 9-27. Retrieved from http://dx.doi.org/10.5465/amle.2010.0072

York, T. T. (2015). More than a desire to serve: A mixed methods exploration of low-income, firstgeneration college students' motivations to participate in service-learning. In A. Tinkler, B. Tinkler, V. Jagla, J. Strait (Eds.), Service-learning to advance social justice (pp. 7-40). Charlotte, NC: Information Age Publishing.

York, T. T., Gibson, C., \& Rankin, S. (2015). Defining and measuring academic success. Practical Assessment, Research and Evaluation, 20(5). Retrieved from http://pareonline.net/getvn.asp? $\mathrm{v}=20 \& \mathrm{n}=5$ 


\section{Appendix A}

Table A1. ANOVA of Independent Variables for LIFG College Students

\begin{tabular}{|c|c|c|c|c|c|c|}
\hline \multicolumn{2}{|c|}{ Variables } & $\begin{array}{r}\text { Sum of } \\
\text { Squares }\end{array}$ & df & $\begin{array}{r}\text { Mean } \\
\text { Square } \\
\end{array}$ & $\mathbf{F}$ & Sig. \\
\hline \multirow{3}{*}{ Male } & Between Groups & 0.816 & 1 & 0.816 & 3.656 & 0.057 \\
\hline & Within Groups & 63.170 & 283 & 0.223 & & \\
\hline & Total & 63.986 & 284 & & & \\
\hline \multirow{3}{*}{ Asian } & Between Groups & 1.915 & 1 & 1.915 & 14.019 & 0.000* \\
\hline & Within Groups & 38.660 & 283 & 0.137 & & \\
\hline & Total & 40.575 & 284 & & & \\
\hline \multirow{3}{*}{ Black } & Between Groups & 0.304 & 1 & 0.304 & 2.333 & 0.128 \\
\hline & Within Groups & 36.903 & 283 & 0.130 & & \\
\hline & Total & 37.207 & 284 & & & \\
\hline \multirow{3}{*}{ Hispanic } & Between Groups & 0.172 & 1 & 0.172 & 0.701 & 0.403 \\
\hline & Within Groups & 69.302 & 283 & 0.245 & & \\
\hline & Total & 69.474 & 284 & & & \\
\hline \multirow{3}{*}{ White } & Between Groups & 0.004 & 1 & 0.004 & 0.037 & 0.847 \\
\hline & Within Groups & 29.940 & 283 & 0.106 & & \\
\hline & Total & 29.944 & 284 & & & \\
\hline \multirow{3}{*}{ Other Race/Ethnicity } & Between Groups & 0.001 & 1 & 0.001 & 0.021 & 0.884 \\
\hline & Within Groups & 11.494 & 283 & 0.041 & & \\
\hline & Total & 11.495 & 284 & & & \\
\hline \multirow{3}{*}{ Multicultural } & Between Groups & 0.106 & 1 & 0.106 & 1.278 & 0.259 \\
\hline & Within Groups & 23.522 & 283 & 0.083 & & \\
\hline & Total & 23.628 & 284 & & & \\
\hline \multirow{3}{*}{$\begin{array}{l}\text { Major: Math \& } \\
\text { Sciences }\end{array}$} & Between Groups & 0.696 & 1 & 0.696 & 3.992 & $0.047 *$ \\
\hline & Within Groups & 49.531 & 284 & 0.174 & & \\
\hline & Total & 50.227 & 285 & & & \\
\hline \multirow{3}{*}{ Major: Humanities } & Between Groups & 0.911 & 1 & 0.911 & 4.978 & 0.026* \\
\hline & Within Groups & 51.956 & 284 & 0.183 & & \\
\hline & Total & 52.867 & 285 & & & \\
\hline \multirow{3}{*}{$\begin{array}{l}\text { Major: Social } \\
\text { Sciences }\end{array}$} & Between Groups & 2.662 & 1 & 2.662 & 13.870 & $0.000 *$ \\
\hline & Within Groups & 54.516 & 284 & .192 & & \\
\hline & Total & 57.178 & 285 & & & \\
\hline \multirow{3}{*}{ Major: Pre-Professional } & Between Groups & .265 & & .265 & 1.932 & .166 \\
\hline & Within Groups & 39.011 & 284 & .137 & & \\
\hline & Total & 39.276 & 285 & & & \\
\hline \multirow{3}{*}{ Major: Other } & Between Groups & 0.128 & 1 & 0.128 & 1.605 & 0.206 \\
\hline & Within Groups & 22.686 & 284 & 0.080 & & \\
\hline & Total & 22.815 & 285 & & & \\
\hline \multirow{3}{*}{ High School GPA } & Between Groups & 4.846 & 1 & 4.846 & 3.180 & 0.076 \\
\hline & Within Groups & 428.222 & 281 & 1.524 & & \\
\hline & Total & 433.067 & 282 & & & \\
\hline
\end{tabular}




\begin{tabular}{|c|c|c|c|c|c|c|}
\hline \multicolumn{2}{|c|}{ Variables } & $\begin{array}{r}\text { Sum of } \\
\text { Squares }\end{array}$ & df & $\begin{array}{r}\text { Mean } \\
\text { Square }\end{array}$ & $\mathbf{F}$ & Sig. \\
\hline \multirow{3}{*}{$\begin{array}{l}\text { Community Service } \\
\text { Required in High } \\
\text { School }\end{array}$} & Between Groups & 0.447 & 1 & 0.447 & 2.497 & 0.115 \\
\hline & Within Groups & 50.857 & 284 & 0.179 & & \\
\hline & Total & 51.304 & 285 & & & \\
\hline \multirow{3}{*}{$\begin{array}{l}\text { High School Service- } \\
\text { Learning Participation }\end{array}$} & Between Groups & 2.238 & 1 & 2.238 & 3.836 & 0.051 \\
\hline & Within Groups & 163.938 & 281 & 0.583 & & \\
\hline & Total & 166.177 & 282 & & & \\
\hline \multirow{3}{*}{$\begin{array}{l}\text { High School } \\
\text { Community Service } \\
\text { Participation }\end{array}$} & Between Groups & 6.102 & 1 & 6.102 & 12.560 & 0.000* \\
\hline & Within Groups & 137.498 & 283 & 0.486 & & \\
\hline & Total & 143.600 & 284 & & & \\
\hline \multirow{3}{*}{$\begin{array}{l}\text { TFS View: Racial } \\
\text { discrimination is no } \\
\text { longer a major problem } \\
\text { in America }\end{array}$} & Between Groups & 0.009 & 1 & 0.009 & 0.067 & 0.796 \\
\hline & Within Groups & 34.879 & 273 & 0.128 & & \\
\hline & Total & 34.887 & 274 & & & \\
\hline \multirow{3}{*}{$\begin{array}{l}\text { TFS View: } \\
\text { Realistically, an } \\
\text { individual can do little } \\
\text { to bring about changes } \\
\text { in our society }\end{array}$} & Between Groups & 0.462 & 1 & 0.462 & 2.083 & 0.150 \\
\hline & Within Groups & 60.982 & 275 & 0.222 & & \\
\hline & Total & 61.444 & 276 & & & \\
\hline \multirow{3}{*}{$\begin{array}{l}\text { TFS View: Colleges } \\
\text { should prohibit } \\
\text { racist/sexist speech on } \\
\text { campus }\end{array}$} & Between Groups & 0.306 & 1 & 0.306 & 1.241 & 0.266 \\
\hline & Within Groups & 66.946 & 271 & 0.247 & & \\
\hline & Total & 67.253 & 272 & & & \\
\hline \multirow{3}{*}{$\begin{array}{l}\text { TFS View: Same sex } \\
\text { couples should have the } \\
\text { right to legal marital } \\
\text { status }\end{array}$} & Between Groups & 0.248 & 1 & 0.248 & 1.122 & 0.290 \\
\hline & Within Groups & 59.631 & 270 & 0.221 & & \\
\hline & Total & 59.879 & 271 & & & \\
\hline \multirow{3}{*}{$\begin{array}{l}\text { TFS View: Affirmative } \\
\text { action in college } \\
\text { admissions should be } \\
\text { abolished }\end{array}$} & Between Groups & 0.425 & 1 & 0.425 & 1.887 & 0.171 \\
\hline & Within Groups & 60.777 & 270 & 0.225 & & \\
\hline & Total & 61.202 & 271 & & & \\
\hline \multirow{3}{*}{ Public Institution } & Between Groups & 0.313 & 1 & 0.313 & 1.507 & 0.221 \\
\hline & Within Groups & 59.102 & 285 & 0.207 & & \\
\hline & Total & 59.415 & 286 & & & \\
\hline \multirow{3}{*}{ Institutional Selectivity } & Between Groups & 6399.936 & 1 & 6399.936 & 0.556 & 0.456 \\
\hline & Within Groups & 3279497.801 & 285.000 & 11507.010 & & \\
\hline & Total & 3285897.737 & 286.000 & & & \\
\hline \multirow{3}{*}{ Full-Time Enrollment } & Between Groups & 0.010 & 1.000 & 0.010 & 1.324 & 0.251 \\
\hline & Within Groups & 1.976 & 275.000 & 0.007 & & \\
\hline & Total & 1.986 & 276.000 & & & \\
\hline
\end{tabular}

Note. *Significant at $p \leq 0.05$ 
Table A2. Blocked Regression Model Predicting CIRP Civic Awareness for LIFG Students

\begin{tabular}{|c|c|c|c|c|c|c|c|c|c|c|}
\hline \multirow{2}{*}{$\begin{array}{l}\text { Variables } \\
\text { Student Pre-College Characteristics }\end{array}$} & \multicolumn{2}{|c|}{ M1 } & \multicolumn{2}{|c|}{ M2 } & \multicolumn{2}{|c|}{ M3 } & \multicolumn{2}{|c|}{ M4 } & \multicolumn{2}{|c|}{ M5 } \\
\hline & B & $p$ & B & $p$ & B & $p$ & B & $p$ & B & $p$ \\
\hline (Constant) & 52.157 & 0.000 & 50.729 & 0.000 & 46.508 & 0.000 & 56.669 & 0.000 & 56.469 & 0.000 \\
\hline Male & -0.793 & 0.439 & -0.505 & 0.635 & -0.198 & 0.853 & -0.020 & 0.985 & 0.007 & 0.995 \\
\hline Asian & -2.249 & 0.191 & -2.177 & 0.210 & -1.818 & 0.299 & -1.517 & 0.389 & -1.294 & 0.465 \\
\hline Black & -0.047 & 0.980 & 0.033 & 0.986 & 0.511 & 0.788 & 0.750 & 0.695 & 0.733 & 0.702 \\
\hline Hispanic & 1.181 & 0.458 & 1.184 & 0.457 & 1.350 & 0.400 & 1.584 & 0.330 & 1.622 & 0.317 \\
\hline Other Race/Ethnicity & 0.396 & 0.883 & 0.390 & 0.887 & 0.220 & 0.937 & 0.362 & 0.897 & 0.385 & 0.890 \\
\hline Multicultural & 0.585 & 0.767 & 0.649 & 0.744 & 1.075 & 0.596 & 1.183 & 0.555 & 1.146 & 0.568 \\
\hline $\begin{array}{l}\text { TFS View: Racial discrimination is no longer a major problem in } \\
\text { America }\end{array}$ & -0.403 & 0.776 & -0.450 & 0.750 & 0.139 & 0.924 & -0.004 & 0.998 & -0.066 & 0.964 \\
\hline $\begin{array}{l}\text { TFS View: Realistically, an individual can do little to bring about } \\
\text { changes in our society }\end{array}$ & -1.131 & 0.279 & -1.235 & 0.242 & -0.959 & 0.362 & -1.089 & 0.312 & -1.072 & 0.319 \\
\hline TFS View: College campuses should prohibit racist/sexist speech & 0.644 & 0.501 & 0.600 & 0.537 & 0.526 & 0.589 & 0.313 & 0.749 & 0.270 & 0.783 \\
\hline $\begin{array}{l}\text { TFS View: Same-sex couples should have the right to legal } \\
\text { marital status }\end{array}$ & 1.353 & 0.198 & 1.209 & 0.262 & 1.076 & 0.321 & 1.171 & 0.281 & 1.126 & 0.303 \\
\hline $\begin{array}{l}\text { TFS View: Affirmative action in college admission should be } \\
\text { abolished }\end{array}$ & 0.388 & 0.719 & 0.505 & 0.644 & 0.381 & 0.723 & 0.560 & 0.605 & 0.606 & 0.577 \\
\hline \multicolumn{11}{|l|}{ Student Pre-College Experiences } \\
\hline High School GPA & & & -0.043 & 0.908 & -0.010 & 0.978 & 0.083 & 0.828 & 0.097 & 0.798 \\
\hline High School Service-Learning Participation & & & 0.771 & 0.279 & 0.836 & 0.250 & 0.837 & 0.251 & 0.843 & 0.248 \\
\hline High School Community Service Participation & & & -0.049 & 0.947 & -0.188 & 0.805 & -0.120 & 0.876 & -0.220 & 0.776 \\
\hline Community Service Required in High School & & & 0.374 & 0.745 & 0.338 & 0.769 & 0.384 & 0.743 & 0.335 & 0.774 \\
\hline \multicolumn{11}{|l|}{ Student College Characteristics } \\
\hline Major: Math \& Sciences & & & & & 1.498 & 0.272 & 1.171 & 0.397 & 1.143 & 0.409 \\
\hline Major: Social Sciences & & & & & 3.308 & 0.010 & 3.189 & 0.013 & 3.009 & 0.022 \\
\hline Major: Pre-Professional & & & & & 0.017 & 0.991 & -0.707 & 0.669 & -0.807 & 0.625 \\
\hline Major: Other & & & & & 0.884 & 0.617 & 0.411 & 0.818 & 0.439 & 0.806 \\
\hline Full-Time Enrollment & & & & & 2.613 & 0.620 & 2.946 & 0.582 & 2.830 & 0.595 \\
\hline \multicolumn{11}{|l|}{ Institutional Characteristics } \\
\hline Public Institution & & & & & & & -1.083 & 0.340 & -1.016 & 0.374 \\
\hline Institutional Selectivity & & & & & & & -0.009 & 0.094 & -0.009 & 0.101 \\
\hline \multicolumn{11}{|l|}{ Service-Learning } \\
\hline Participation in Service-Learning Course(s) & & & & & & & & & 0.820 & 0.425 \\
\hline Change in $\mathrm{R}^{2}$ & & 0.057 & & 0.013 & & 0.032 & & 0.018 & & 0.003 \\
\hline$\leq 0 \quad \mathrm{R}^{2}$ & & 0.0570 & & 0.070 & & 0.102 & & 0.120 & & 0.123 \\
\hline
\end{tabular}

Note. $*$ Significant at $p \quad .10 ; * *$ Significant at $p \quad .05 ; * * *$ Significant at $p \quad .001$ 
Table A3. Results for Blocked Regression Model Predicting Cognitive Diversity for LIFG Students

\begin{tabular}{|c|c|c|c|c|c|c|c|c|c|c|}
\hline \multirow{2}{*}{$\begin{array}{c}\text { Variables } \\
\text { Student Pre-College Characteristics }\end{array}$} & \multicolumn{2}{|c|}{ M1 } & \multicolumn{2}{|c|}{ M2 } & \multicolumn{2}{|c|}{ M3 } & \multicolumn{2}{|c|}{ M4 } & \multicolumn{2}{|c|}{ M5 } \\
\hline & B & $p$ & B & $p$ & B & $p$ & B & $p$ & B & $p$ \\
\hline (Constant) & 12.399 & 0.000 & 11.603 & 0.000 & 10.897 & 0.000 & 11.336 & 0.000 & 11.336 & 0.000 \\
\hline Male & 0.065 & 0.782 & 0.115 & 0.630 & 0.138 & 0.564 & 0.145 & 0.546 & 0.146 & 0.544 \\
\hline Asian & -0.143 & 0.705 & -0.163 & 0.669 & -0.172 & 0.656 & -0.158 & 0.684 & -0.158 & 0.687 \\
\hline Black & 0.516 & 0.199 & 0.519 & 0.200 & 0.586 & 0.157 & 0.598 & 0.155 & 0.598 & 0.157 \\
\hline Hispanic & 0.558 & 0.109 & 0.558 & 0.112 & 0.523 & 0.138 & 0.534 & 0.137 & 0.534 & 0.137 \\
\hline Other Race/Ethnicity & 0.385 & 0.509 & 0.424 & 0.472 & 0.377 & 0.529 & 0.382 & 0.524 & 0.382 & 0.524 \\
\hline Multicultural & -0.292 & 0.517 & -0.260 & 0.569 & -0.197 & 0.675 & -0.195 & 0.679 & -0.195 & 0.679 \\
\hline $\begin{array}{l}\text { TFS View: Racial discrimination is no longer a major problem in } \\
\text { America }\end{array}$ & -0.061 & 0.825 & -0.042 & 0.881 & 0.047 & 0.871 & 0.040 & 0.891 & 0.040 & 0.893 \\
\hline $\begin{array}{l}\text { TFS View: Realistically, an individual can do little to bring about } \\
\text { changes in our society }\end{array}$ & -0.092 & 0.684 & -0.094 & 0.682 & -0.062 & 0.789 & -0.067 & 0.769 & -0.068 & 0.768 \\
\hline TFS View: Colleges should prohibit racist/sexist speech on campus & -0.028 & 0.890 & -0.028 & 0.892 & -0.029 & 0.892 & -0.038 & 0.860 & -0.038 & 0.859 \\
\hline TFS View: Same-sex couples should have the legal right marry & 0.011 & 0.960 & 0.014 & 0.948 & -0.040 & 0.856 & -0.035 & 0.872 & -0.035 & 0.873 \\
\hline $\begin{array}{l}\text { TFS View: Affirmative action in college admission should be } \\
\text { abolished }\end{array}$ & -0.478 & $0.029 * *$ & -0.469 & $0.033 * *$ & -0.494 & $0.024 * *$ & -0.487 & $0.028 * *$ & -0.487 & $0.028 * *$ \\
\hline \multicolumn{11}{|l|}{ Student Pre-College Experiences } \\
\hline High School GPA & & & 0.062 & 0.435 & 0.059 & 0.467 & 0.063 & 0.441 & 0.063 & 0.443 \\
\hline High School Service-Learning Participation & & & 0.049 & 0.753 & 0.084 & 0.602 & 0.086 & 0.598 & 0.086 & 0.598 \\
\hline High School Community Service Participation & & & 0.064 & 0.695 & 0.039 & 0.819 & 0.041 & 0.813 & 0.040 & 0.815 \\
\hline Community Service Required in High School & & & 0.106 & 0.673 & 0.087 & 0.726 & 0.087 & 0.729 & 0.086 & 0.732 \\
\hline \multicolumn{11}{|l|}{ Student College Characteristics } \\
\hline Major: Math \& Sciences & & & & & 0.188 & 0.523 & 0.176 & 0.559 & 0.177 & 0.559 \\
\hline Major: Social Sciences & & & & & 0.291 & 0.305 & 0.288 & 0.313 & 0.287 & 0.319 \\
\hline Major: Pre-Professional & & & & & -0.402 & 0.220 & -0.433 & 0.212 & -0.434 & 0.210 \\
\hline Major: Other & & & & & -0.137 & 0.728 & -0.158 & 0.692 & -0.158 & 0.692 \\
\hline Full-Time Enrollment & & & & & 0.714 & 0.513 & 0.737 & 0.503 & 0.738 & 0.506 \\
\hline \multicolumn{11}{|l|}{ Institutional Characteristics } \\
\hline Public Institution & & & & & & & -0.056 & 0.821 & -0.056 & 0.822 \\
\hline Institutional Selectivity & & & & & & & 0.000 & 0.741 & 0.000 & 0.742 \\
\hline \multicolumn{11}{|l|}{ Service-Learning } \\
\hline Participation in Service-Learning Course(s) & & & & & & & & & 0.004 & 0.987 \\
\hline Change in $\mathrm{R}^{2}$ & & 0.103 & & 0.008 & & 0.019 & & 0.003 & & 0.000 \\
\hline $\mathrm{R}^{2}$ & & 0.103 & & 0.111 & & 0.130 & & 0.133 & & 0.133 \\
\hline
\end{tabular}


339 | International Journal of Research on Service-Learning and Community Engagement

$$
\leq 0 \quad \leq 0 \quad \leq 0
$$

Note. $*$ Significant at $p \quad .10 . * *$ Significant at $p \quad .05 . * * *$ Significant at $p \quad .001$. 


\section{Appendix B}

Table B1. Study Variables

\section{Independent Variables}

Service-Learning

Service-Learning: "Since entering college, indicate how often you have performed community service as part of a class?" (reconstructed as a dichotomous variable, $0=\mathrm{No}, 1=\mathrm{Yes}$ ) [ACT09]

\section{Student Characteristics}

Student Demographics

Race/Ethnicity Group: "Please indicate your racial/ethnic background." (dummy coded, $0=$ White, 1=American Indian, 2=Asian, 3=Black, 4=Hispanic, 5=Other, 6=Multicultural) [RACEGROUP]

Sex: "Your sex:" (dummy coded, 1=Male, 0=Female) [SEX -307]

Student Pre-College Characteristics

High School GPA: What was your average grade in high school? $\left(1=\mathrm{D}, 2=\mathrm{C}, 3=\mathrm{C}+, 4=\mathrm{B}-,{ }^{-}=\mathrm{B}, 6=\mathrm{B}+, 7=\mathrm{A}-,{ }^{-}=\mathrm{A}\right.$ or A+) [HSGPA_TFS]

Community Service Required in High School: Did your high school require community service for graduation? $(0=$ No, $1=$ Yes $)$ [CSVREQ_TFS]

High School Service-Learning Participation: Indicate which activities you did in the past year: Performed community service as part of a class? $(0=\mathrm{No}, 1=$ Yes $)$ [ACT20_TFS]

High School Community Service Participation: Indicate which activities you did in the past year: performed volunteer work? $(0=$ No, $1=$ Yes $)$ [ACT12_TFS]

Student College Characteristics

Major: Primary undergraduate majors were grouped in the following categories and dummy coded with Humanities as the reference group: Humanities ( $6=$ English, $9=$ Humanities, $8=$ History or Political Science, and 10=Fine Arts), Math \& Sciences (1=Agriculture, 2=Biological Sciences, 5=Engineering, 11=Mathematics or Statistics, and 12=Physical Sciences), Social Sciences (13=Social Sciences), PreProfessional ( $3=$ Business, 4=Education, and 7=Heath Professional), Other (14=Other Technical, 15=Other Non-technical, \& 16=Undecided)

Enrollment Status: “Are you enrolled (or enrolling) as a...” (1=Part-time Student, 2=Full-time student)

Full-Time Enrollment: Dichotomous variable derived from "enrollment status" $(0=$ No, $1=$ Yes $)$.

$\underline{\text { Socioeconomic Status }}$

Parents' Income: “What is your best estimate of your parents' total income last year?" (1=Less than $\$ 10,000$, $2=\$ 10,000$ to $14,999,3=\$ 15,000$ to $19,999,4=\$ 20,000$ to $24,999,5=\$ 25,000$ to $29,999,6=\$ 30,000$ to 39,999 , $7=\$ 40,000$ to $49,999,8=\$ 50,000$ to $59,999,9=\$ 60,000$ to $74,999,10=\$ 75,000$ to $99,999,11=\$ 100,000$ to $149,999,12=\$ 150,000$ to $199,999,13=\$ 200,000$ to $249,999,14=\$ 250,000$ or more) [INCOME_TFS]

Parents' Education: Father's education; Mother's education ( $1=$ Grammar school or less, $2=$ Some high school, $3=$ High school graduate, $4=$ Postsecondary school other than college, $5=$ Some college, $6=$ College degree, 7=Some graduate school, $8=$ Graduate degree) [FATHEDUC_TFS-485]; [MOTHEDUC_TFS]

First Generation (Derived from above): "First generation status based on parent(s) with less than 'some college'" $(1=$ No, $2=$ Yes $)$ [FIRSTGEN_TFS] 


\section{Student Outcomes (Dependent Variables)}

Academic Skills

College GPA: Grade-point-average $(1=\mathrm{D}, 2=\mathrm{C}, 3=\mathrm{C}+, 4=\mathrm{B}-, 5=\mathrm{B}, 6=\mathrm{B}+, 7=\mathrm{A}-, 8=\mathrm{A}$ or $\mathrm{A}+)$ [COLLGPA]

Growth in Critical Thinking Skills: "Compared with when you entered college as a freshman, how would you now describe your ability to think critically?" ( $1=$ much weaker, $2=$ weaker, $3=$ no change, $4=$ stronger, $5=$ much stronger) [SLFCHG04]

Growth in Problem-Solving Skills: "Compared with when you entered college as a freshman, how would you now describe your analytical and problem-solving skills? ( $1=$ much weaker, $2=$ weaker, $3=$ no change, $4=$ stronger, $5=$ much stronger) [SLFCHG02]

Diversity Skills

Growth in Cultural Understanding: "Compared with when you entered college as a freshman, how would you now describe your knowledge of people from different races/cultures?" (1= much weaker, $2=$ weaker, $3=$ no change, $4=$ stronger, $5=$ much stronger) [SLFCHG05]

Growth in Leadership: "Compared with when you entered college as a freshman, how would you now describe your leadership abilities?" ( $1=$ much weaker, $2=$ weaker, $3=$ no change, $4=$ stronger, $5=$ =much stronger $)$ [SLFCHG06]

Growth in Interpersonal Skills: "Compared with when you entered college as a freshman, how would you now describe your interpersonal skills?" ( $1=$ much weaker, $2=$ =eaker, $3=$ no change, $4=$ stronger, $5=$ much stronger) [SLFCHG07]

Growth in Diversity Skills: "Compared with when you entered college as a freshman, how would you now describe your ability to get along with people of different races/cultures?" ( $1=$ much weaker, $2=$ weaker, $3=$ no change, $4=$ stronger, $5=$ much stronger) $[\mathrm{SLFCHG08}]$

Civic Awareness Scale

CSS Civic Awareness Score ( $1=$ Low score, $2=$ Average Score, $3=$ High score) [CIVIC_AWARENESS] Derived from the following three items:

1. Growth in understanding of Social Problems Facing our Nation: "Compared with when you entered college as a freshman, how would you now describe your understanding of social problems facing our nation?" ( $1=$ much weaker, $2=$ weaker, $3=$ no change, $4=$ stronger, $5=$ much stronger) [SLFCHG10 -130] (weight $=7.88$ )

2. Growth in understanding Global Issues: "Compared with when you entered college as a freshman, how would you now describe your understanding global issues?" ( $1=$ much weaker, $2=$ weaker, $3=$ no change, $4=$ stronger, 5=much stronger) [SLFCHG14 -134] (weight=3.32)

3. Growth in understanding of the problems facing your community: "Compared with when you entered college as a freshman, how would you now describe your understanding of the problems facing your community?" (1= much weaker, $2=$ weaker, $3=$ no change, $4=$ stronger, $5=$ much stronger) [SLFCHG09 -129] (weight=2.09)

\section{Other Outcome Variables (DV)}

Self-Reported Change

"Compared with when you entered this college, how would you now describe your:" (1=Much weaker,

$2=$ Weaker, $3=$ No change, $4=$ Stronger, $5=$ Much stronger) ${ }^{* *}$ Each of the following are individual items.

- Knowledge of people from different races/cultures [SLFCHG05]

- Ability to get along with people of different races/cultures [SLFCHG08]

- Understanding of the problems facing your community [SLFCHG09]

- Understanding of social problems facing our nation [SLFCHG10]

- Understanding of global issues [SLFCHG14]

Views

"Please indicate your agreement with each of the following statements:" ( $1=$ Disagree strongly, $2=$ Disagree somewhat, $3=$ Agree somewhat, $4=$ Agree strongly) $* *$ Each of the following are individual items.

- Racial discrimination is no longer a major problem in America [VIEW06 \& VIEW06_TFS]

- Realistically, an individual can do little to bring about changes in our society [VIEW07 \& 


\section{VIEW07_TFS]}

- View: Colleges should prohibit racist/sexist speech on campus [VIEW08 \& VIEW08_TFS]

- View: Same sex couples should have the right to legal marital status [VIEW09 \& VIEW09_TFS]

- Affirmative action in college admissions should be abolished [VIEW10 \& VIEW11_TFS]

Goals

"Indicate the importance to you personally of each of the following:" (1=Not important, $2=$ Somewhat important, $3=$ Very important, $4=$ Essential) $* *$ Each of the following are individual items.

- Influencing the political structure [GOAL04 \& GOAL04_TFS]

- Influencing social values [GOAL05 \& GOAL05_TFS]

- Helping others who are in difficulty [GOAL09 \& GOAL09_TFS]

- Participating in a community action program [GOAL16 \& GOAL16_TFS]

- Helping to promote racial understanding [GOAL17 \& GOAL17_TFS]

- Keeping up to date with political affairs [GOAL18 \& GOAL18_TFS]

- Becoming a community leader [GOAL19 \& GOAL19_TFS]

- Improving my understanding of other countries and cultures [GOAL20 \& GOAL21_TFS]

\section{Institutional Characteristics}

College I.D.: I.D. number assigned by HERI for each institution; institutional identity remains confidential. [ACE]

Institutional Control: Institution Control ( $1=$ Public, $2=$ Private) [INSTCONT]

Institutional Type: Institution Type ( $1=$ University, $2=4$-year, $3=2$-year) [INSTTYPE]

Institutional Selectivity: Institutional selectivity (Very Low, Low; Medium; High, Very High) [SELECTIVITY] 